\title{
Constitutional Rights in Kansas After Hodes \& Nauser
}

\author{
Richard E. Levy*
}

\section{INTRODUCTION}

In Hodes \& Nauser, MDs, P.A. v. Schmidt, ${ }^{1}$ the Kansas Supreme Court held that section 1 of the Kansas Constitution's Bill of Rights protects a woman's fundamental right "to make her own decisions regarding her body, health, family formation, and family life - decisions that can include whether to continue a pregnancy." 2 For the most part, reactions to this long-awaited and controversial decision fell along predictable lines, with pro-choice advocates hailing the decision as an important advancement for women's reproductive freedoms, and right to life advocates condemning the decision and vowing to reverse it by state constitutional amendment. ${ }^{3}$ In this Article, I will leave those important but intractable debates to one side and focus on a more practical question: What are the implications of Hodes \& Nauser for the interpretation and application of constitutional rights in Kansas?

The central premise of this Article is that Hodes \& Nauser decouples Kansas individual rights doctrine from the United States Supreme Court's constitutional rights jurisprudence, with significant implications not only for abortion rights but also for many other constitutional rights. ${ }^{4}$ When

\footnotetext{
* J.B. Smith Distinguished Professor of Constitutional Law, University of Kansas School of Law. The views expressed in this Article are solely those of the author and do not represent the views of the University of Kansas or the School of Law.

1. 440 P.3d 461, 466 (Kan. 2019) (upholding a trial court order granting a preliminary injunction to prevent enforcement of the Kansas Unborn Child Protection from Dismemberment Abortion Act, KAN. STAT. ANN. §§ 65-6741 to 66-6749 (West 2018), which prohibits the dilation and evacuation abortion procedure).

2. Id.

3. See, e.g., Celia LLopis-Jepsen, Kansas Lawmakers Want to Block the Right to Abortion by Changing the State Constitution, KCUR 89.3 (Jan. 22, 2020), https://www.kcur.org/post/kansas -lawmakers-want-block-right-abortion-changing-state-constitution\#stream $/ 0$ [https://perma.cc/5T32 -ZJQP]; Jonathan Shorman, Kansas Moving Closer to 2020 Showdown Over Abortion After Supreme Court Decision, Wichita EAGLe (Oct. 1, 2019, 6:14 PM), https://www-1.kansas.com/news/politics -government/article235683267.html\# [https://perma.cc/LW8L-4XKE].

4. Because this Article analyzes the implications of the Hodes \& Nauser decision, it focuses on the per curiam opinion of the court and will not attempt to summarize the differing views expressed
} 
interpreting their own constitution's individual rights protections, state supreme courts are not directly bound by United States Supreme Court decisions respecting similar rights under the United States Constitution. Federal constitutional rights establish a minimum set of rights that state governments must respect, even when their respective state constitutions would not protect those rights. ${ }^{5}$ Although states often align their own constitutional jurisprudence with federal precedents, they are free to provide greater protection for individual rights under their own constitutions than the federal minimum.

The Kansas Supreme Court might have reached the same result in Hodes \& Nauser by aligning the Kansas Bill of Rights' protections with the United States Supreme Court's decision in Planned Parenthood of Southeastern Pennsylvania v. Casey, ${ }^{6}$ under which the right to an abortion is a "liberty interest" and regulations impinging on that liberty interest are evaluated under the "undue burden" test. ${ }^{7}$ Instead, the Kansas Supreme Court held that the decision to have an abortion is a component of a woman's inalienable natural right of personal autonomy protected by section 1 , and that strict scrutiny is the proper test for analyzing laws that burden abortion rights. ${ }^{8}$ Under strict scrutiny, such laws must serve a "compelling governmental interest" and be "narrowly tailored" to further that interest. ${ }^{9}$

This analysis represents a repudiation not only of Casey, but also of the broader doctrinal approach that Casey epitomizes. As will be developed more fully below, the United States Supreme Court's precedents in the Warren and Burger Courts crystalized into a

in the concurring and dissenting opinions. See Hodes \& Nauser, 440 P.3d at 504-17 (Biles, J., concurring) (agreeing with the majority that section 1 protects a fundamental right to determine whether to continue a pregnancy but arguing in favor of the "evidence-based analytical model" of Whole Woman's Health v. Hellerstedt, 136 S. Ct. 2292 (2016)); id. at 517-57 (Stegall, J., dissenting) (arguing that section 1 should be read as a general constraint on the police power enforced using the rational basis test rather than a mechanism for enhanced protection of a limited set of fundamental rights).

5. Accordingly, when parties assert both state and federal rights, state courts may elect to resolve them solely on the basis of federal law so as to avoid elaborating on the state constitution unnecessarily. Thus, for example, in Oklahoma Coalition for Reproductive Justice v. Cline, the Oklahoma Supreme Court referenced Hodes \& Nauser but found it unnecessary to determine whether the Oklahoma Constitution protected abortion rights because the law was invalid under federal precedents that the court was bound to apply. 441 P.3d 1145, 1151 (Okla. 2019). The Kansas Supreme Court did not have that option in Hodes \& Nauser because the plaintiffs explicitly declined to rely on federal law. 440 P.3d at $466,471$.

6. 505 U.S. $833,915-17$ (1992).

7. That was the approach taken by the district court and court of appeals plurality in Hodes \& Nauser. See 440 P.3d at 499-500 (discussing the trial court's reasoning); id. at 504-17 (Biles, J., concurring) (arguing in favor of the approach used in Whole Woman's Health).

8. See infra Section II.B (discussing the Kansas Supreme Court's analysis in Hodes \& Nauser).

9. See infra notes 45-46 and accompanying text (discussing the levels of ends-means scrutiny). 
comprehensive fundamental rights framework based upon a broad conceptual understanding of rights and strict scrutiny of laws burdening rights the Court deemed fundamental. ${ }^{10}$ The Rehnquist and Roberts Courts, however, have taken a right-specific approach that demands independent constitutional justification for specific rights claims, applying this approach to reject the expansion of existing rights and narrow or weaken many rights previously recognized as fundamental. ${ }^{11}$ Casey is a particularly relevant example of this approach. ${ }^{12}$

Thus, Hodes \& Nauser rejected not only Casey, but also the rightspecific approach of the Rehnquist and Roberts Courts. Instead, the Kansas Supreme Court linked Kansas constitutional doctrine to the fundamental rights approach employed by the Warren and Burger Courts. The analysis in Hodes \& Nauser therefore has important implications not only for abortion rights in Kansas but also for the broader jurisprudence of constitutional rights under the Kansas Bill of Rights. ${ }^{13}$ This Article develops and explores this thesis in two steps. Part II examines Hodes \& Nauser in context, contrasting federal constitutional rights jurisprudence with the Kansas Supreme Court's section 1 analysis. Part III then considers the implications of Hodes \& Nauser's analysis for three types of rights: abortion rights, other rights under section 1, and other provisions of the Kansas Constitution's Bill of Rights. In conclusion, Part IV summarizes these implications and offers some additional observations.

\section{HODES \& NAUSER IN CONTEXT}

To lay the foundations for the discussion of its implications, this Part focuses on understanding the Hodes \& Nauser decision in context. The discussion begins with a brief primer on constitutional rights doctrine in relation to the right of abortion so as to frame the critical questions confronting the Kansas Supreme Court in Hodes \& Nauser. It then highlights two key aspects of the Hodes \& Nauser decision: (1) the court's approach to the recognition of constitutional rights as applied to abortion rights; and (2) the application of strict scrutiny to invalidate the law in

10. See infra Section II.A.1. It was this framework that produced Roe v. Wade, 410 U.S. 113 (1973).

11. See infra Section II.A.2 (discussing the modern Court's right-specific approach).

12. See 505 U.S. at $853-54$ (purporting to preserve the "central holding" of Roe). For further discussion of Casey, see infra notes 77-80 and accompanying text.

13. See, e.g., Hilburn v. Enerpipe, Ltd., 442 P.3d 509, 513 (Kan. 2019) (relying on Hodes \& Nauser to invalidate a statutory damages cap as a violation of the right to a jury under section 5 of the Kansas Bill of Rights). Although Hilburn is the only judicial decision to do so at the time of this writing, many litigants have relied on Hodes \& Nauser to argue for enhanced protection for a variety of other rights. See infra Part III. 
question.

\section{A. A Brief Primer on Constitutional Rights Doctrine}

For well over a century, the United States Supreme Court has applied the Fourteenth Amendment to the United States Constitution to protect certain constitutional rights against infringement by state governments. The initial focus of the Court's precedents was the protection of property rights and freedom of contract, but those precedents laid the foundation for the protection of other rights, including the so-called right of privacy. By the 1960s and 1970s, the resulting doctrine had crystalized into what this Article will refer to as the "fundamental rights" approach to individual rights that was favored by the "liberal" Warren and Burger Courts. ${ }^{14}$ With the appointment of more "conservative" Justices, the fundamental rights approach eroded and the Rehnquist and Roberts Courts' jurisprudence moved toward what this Article will refer to as a "right-specific" approach. Both of these developments were crucial to the evolution of abortion rights doctrine before Hodes \& Nauser.

\section{The Fundamental Rights Approach}

The fundamental rights approach crystalized during the 1960s and 1970s as the culmination of a series of interrelated developments that had their roots in the so-called Lochner era (from the 1890s through the 1930s). ${ }^{15}$ Under the fundamental rights approach, most laws were subject to the deferential rational basis test, and were upheld if they were rationally related to any legitimate governmental purpose. ${ }^{16}$ Government action that burdened fundamental rights, however, triggered strict scrutiny, and could be upheld only if it was necessary to further a compelling governmental interest. ${ }^{17}$ Rights were deemed fundamental if they were deeply rooted in our traditions, implicit in the concept of ordered liberty, or preservative of

14. For convenience, this Article uses the terms "liberal" and "conservative" in accordance with their conventional current usage, while recognizing that both terms are poorly defined, highly malleable, and frequently changing.

15. See generally David E. Bernstein, Lochner Era Revisionism, Revised: Lochner and the Origins of Fundamental Rights Constitutionalism, 92 GEO. L.J. 1 (2003).

16. See, e.g., Feguson v. Skrupa, 372 U.S. 726, 733 (1963) (applying the rational basis test to uphold statute requiring a law license to engage in practice of debt adjustment); Williamson v. Lee Optical of Okla., Inc., 348 U.S. 483, 491 (1955) (applying the rational basis test to uphold statute requiring prescription from optometrist or ophthalmologist to duplicate or replace eyeglass lenses).

17. See, e.g., Roe v. Wade, 410 U.S. 113 (1973) (concluding that a woman's decision to terminate a pregnancy is within the fundamental right of privacy and applying strict scrutiny to invalidate law criminalizing abortion). 
other rights. ${ }^{18}$ In addition, once a fundamental right was recognized, the Court could expand it conceptually, bringing new interests under the penumbra of that right. ${ }^{19}$

In the decades following the Civil War, the Supreme Court was reluctant to read the Fourteenth Amendment broadly as a source of constitutional rights that limited the states. Critically, the Court's decision in the Slaughter-House Cases $^{20}$ all but eliminated the Privileges and Immunities Clause of the Fourteenth Amendment as a source of constitutional rights. ${ }^{21}$ During the Lochner era, however, the Court began to use the Fourteenth Amendment as a source of rights protections against state action. In light of the Slaughterhouse Cases, the Court could not rely on the Privileges and Immunities Clause, so it relied on the Due Process Clause of the Fourteenth Amendment instead. ${ }^{22}$

Under the doctrine of substantive due process, individual liberties could only be regulated by the state pursuant to valid exercises of the police power. As reflected in Lochner itself, ${ }^{23}$ the primary focus of substantive due process was the protection of contract and property rights and the Court often scrutinized carefully the alleged police-power justifications for state laws burdening those rights. This approach was part of a broader pattern of decisions and doctrines through which the Court invalidated federal and state regulation of business activity. ${ }^{24}$ This aspect

18. See, e.g., Rochin v. California, 342 U.S. 165, 169 (1952) ("Due process of law is a summarized constitutional guarantee of respect for those personal immunities which, as Mr. Justice Cardozo twice wrote for the Court, are 'so rooted in the traditions and conscience of our people as to be ranked as fundamental', or are 'implicit in the concept of ordered liberty."' (first quoting Snyder v. Massachusetts, 291 U.S. 97, 105 (1934); and then quoting Palko v. Connecticut, 302 U.S. 319, 325 (1937))).

19. See, e.g., Carey v. Population Servs., Int'l, 431 U.S. 678, 684-85 (1977) ("This right of personal privacy includes the interest in independence in making certain kinds of important decisions. While the outer limits of this aspect of privacy have not been marked by the Court, it is clear that among the decisions that an individual may make without unjustified government interference are personal decisions relating to marriage, procreation, contraception, family relationships, and child rearing and education." (internal quotation marks and citations omitted)).

20. 83 U.S. (16 Wall.) 36 (1873).

21. Specifically, the Court held that the Clause protected only the rights of United States citizenship, which by definition did not include the rights of state citizenship, which are protected by the Privileges and Immunities Clause of Article IV. Id. at 72-74. Accordingly, any right that was attributable to state citizenship was not a right of national citizenship. See id. Since the courts previously read those rights broadly, there were few, if any, rights attributable to national citizenship. See id. at 75-80.

22. See, e.g., Allgeyer v. Louisiana, 165 U.S. 578 (1897) (relying on the Due Process Clause of the Fourteenth Amendment to invalidate a state law that interfered with liberty of contract).

23. Lochner v. New York, 198 U.S. 45, 64-65 (1905) (invalidating a law that limited the hours of bakery workers as an improper infringement on liberty of contract because limiting the hours of bakery workers was not necessary to protect the public health or the health of bakery workers).

24. See Richard E. Levy, Escaping Lochner's Shadow: Toward A Coherent Jurisprudence of 
of the Court's Lochner-era jurisprudence was later repudiated, and the case came to symbolize improper judicial activism. ${ }^{25}$

The roots of modern privacy doctrine also lie in the Lochner era. Most directly, in Meyer v. Nebraska ${ }^{26}$ and Pierce v. Society of Sisters, ${ }^{27}$ the Court held that due process protects the rights of parents to the custody and care of their children. In Meyer, the Court declared broadly:

[The "liberty" protected by due process] denotes not merely freedom from bodily restraint but also the right of the individual to contract, to engage in any of the common occupations of life, to acquire useful knowledge, to marry, establish a home and bring up children, to worship God according to the dictates of his own conscience, and generally to enjoy those privileges long recognized at common law as essential to the orderly pursuit of happiness by free men. ${ }^{28}$

Equally important, the Court began during the Lochner era to incorporate provisions of the Bill of Rights via the Due Process Clause of the Fourteenth Amendment so as to make them applicable to the states. ${ }^{29}$ Perhaps predictably, considering the Court's focus on contract and property rights, the Takings Clause was the first Bill of Rights provision made applicable to the states via the Due Process Clause of the Fourteenth Amendment. ${ }^{30}$ The Court, however, also applied some First Amendment protections against the states during the Lochner era. ${ }^{31}$ The incorporation doctrine further solidified the role of the Due Process Clause as a source of fundamental rights.

Economic Rights, 73 N.C. L. REV. 329, 342-44 (1995) [hereinafter Levy, Escaping Lochner's Shadow] ("During the Lochner era, of course, the Court stood in opposition to an ever-increasing tide of economic and social legislation. Relying on substantive economic due process, as well as other substantive and structural doctrines to invalidate regulatory efforts at the state and federal levels, the Court effectively constitutionalized the laissez-faire jurisprudence of the common law." (footnotes omitted)).

25. See, e.g., Ferguson v. Skrupa, 372 U.S. 726, 730 (1963) ("The doctrine that prevailed in Lochner ... and like cases - that due process authorizes courts to hold laws unconstitutional when they believe the legislature has acted unwisely — has long since been discarded. We have returned to the original constitutional proposition that courts do not substitute their social and economic beliefs for the judgment of legislative bodies, who are elected to pass laws.").

26. 262 U.S. 390 (1923).

27. 268 U.S. 510 (1925).

28. 262 U.S. at 399.

29. See generally McDonald v. City of Chicago, 561 U.S. 742, 759-66 (2010) (providing a detailed account of the history and evolution of the incorporation doctrine).

30. Chi., Burlington \& Quincy R.R. Co. v. Chicago, 166 U.S. 226, 258 (1897) (incorporating Fifth Amendment prohibition on taking of private property for public use without just compensation).

31. See Near v. Minnesota, 283 U.S. 697 (1931) (freedom of the press); Stromberg v. California, 283 U.S. 359, 376 (1931) (freedom of speech); Gitlow v. New York, 268 U.S. 652 (1925) (same); see also Powell v. Alabama, 287 U.S. 45 (1932) (applying the Sixth Amendment right to counsel against the states). 
In 1937, the Court abruptly abandoned its antiregulatory jurisprudence, overruling and repudiating many of its Lochner era precedents. ${ }^{32}$ Nonetheless, the prior doctrine continued to influence the Court's emerging fundamental rights jurisprudence. Thus, although the Court emphasized deference to legislative judgements concerning the police powers, it continued to engage in substantive review of state and federal laws. Critically, even as it announced an extraordinarily deferential form of rational basis review for regulations burdening property and contract rights in United States v. Carolene Products Co., ${ }^{33}$ the Court hinted in a famous footnote that it would employ more aggressive forms of review for some types of regulations. ${ }^{34}$ This footnote also preserved Meyer and Pierce as viable precedents. ${ }^{35}$

Another important doctrinal development was the use of the Equal Protection Clause to protect fundamental rights, which likely reflected the Court's reluctance to rely on due process for protection of nontextual rights in the aftermath of the Lochner era. The use of equal protection to justify strict scrutiny of state laws burdening fundamental rights originated in Skinner v. Oklahoma ex rel. Williamson, which invalidated a state law providing for compulsory sterilization of persons convicted three times for specified criminal offenses. ${ }^{36}$ The Court emphasized that the law involved "one of the basic civil rights of man" and that "[m]arriage and procreation are fundamental to the very existence and survival of the race." 37 Accordingly, the Court explained, "strict scrutiny of the classification which a State makes in a sterilization law is essential, lest unwittingly, or

32. See Levy, Escaping Lochner's Shadow, supra note 24, at 344-45 ("The Lochner era ended abruptly in 1937 with the famous 'switch in time that saved nine,' which marked the beginning of an era of liberal constitutional jurisprudence. Since that time, the Court has routinely rejected challenges to economic regulation regardless of the substantive or structural provisions invoked to protect economic rights, by applying the deferential rational basis test. Under this test, the government need only show that a measure is reasonably related to some conceivable legitimate purpose." (footnotes omitted)).

33. 304 U.S. 144, 152 (1938) ("[T]he existence of facts supporting the legislative judgment is to be presumed, for regulatory legislation affecting ordinary commercial transactions is not to be pronounced unconstitutional unless in the light of the facts made known or generally assumed it is of such a character as to preclude the assumption that it rests upon some rational basis within the knowledge and experience of the legislators.").

34. Id. at 152 n.4.

35. See id. ("Nor need we enquire whether similar considerations enter into the review of statutes directed at particular religious, Pierce v. Society of Sisters, or national, Meyer v. Nebraska, or racial minorities; whether prejudice against discrete and insular minorities may be a special condition, which tends seriously to curtail the operation of those political processes ordinarily to be relied upon to protect minorities, and which may call for a correspondingly more searching judicial inquiry." (citations omitted)). In so doing, the Court characterized these decisions as discrimination cases, rather than fundamental rights cases.

36. 316 U.S. 535,536 (1942).

37. Id. at 541 . 
otherwise invidious discriminations are made against groups or types of individuals in violation of the constitutional guaranty of just and equal laws." 38 After Skinner, fundamental rights could receive enhanced protection under both the Due Process and Equal Protection Clauses.

A final doctrinal development in the post-Lochner period was the expanding use of the incorporation doctrine to hold that provisions of the Bill of Rights applied to the states. The Court endorsed this approach in Carolene Products, which observed that " $\mathrm{t}] \mathrm{h}$ here may be narrower scope for operation of the presumption of constitutionality when legislation appears on its face to be within a specific prohibition of the Constitution, such as those of the first ten Amendments, which are deemed equally specific when held to be embraced within the Fourteenth." 39 In a series of decisions that produced a famous debate over the proper relationship between the Bill of Rights, the Fourteenth Amendment, and the states, the Court eventually settled on an approach known as "selective incorporation." 40 Under this approach, a provision of the Bill of Rights would be incorporated into the Fourteenth Amendment's Due Process Clause and apply to the states if it was "so rooted in the traditions and conscience of our people as to be ranked as fundamental" 41 or "implicit in the concept of ordered liberty." 42

Building on these developments, during the 1960s and 1970s, the Court's constitutional rights jurisprudence crystalized into a single overarching framework that merged due process and equal protection analysis. Under this approach, government action would be reviewed under one of three levels of ends-means scrutiny. The baseline level of scrutiny, the rational basis test, would apply unless there was a reason to apply a heightened form of scrutiny. ${ }^{43}$ Under the rational basis test, government action is presumptively valid and the burden is on the party

\footnotetext{
38. $I d$.

39. 304 U.S. at 152 n.4 (emphasis added).

40. See Jerold H. Israel, Selective Incorporation: Revisited, 71 GEO. L.J. 253, 253 (1982). For a recent and somewhat controversial application of the incorporation doctrine, see Ramos v. Louisiana, 140 S. Ct. 1390 (2020) (concluding that the Sixth Amendment right to counsel as incorporated and applied against the states requires unanimous verdicts to convict defendants of major offenses and overruling contrary precedent that applied different rules in federal and state prosecutions).

41. Snyder v. Massachusetts, 291 U.S. 97, 105 (1934).

42. Palko v. Connecticut, 302 U.S. 319, 325 (1937). This test could be stated in various ways, some of which were broader than others, but in all its forms it retained the same two basic components - one that focused on the historical recognition of a right and the other focused on its centrality to the concept of liberty.

43. See, e.g., Ferguson v. Skrupa, 372 U.S. 726, 733 (1963) (applying the rational basis test to uphold a statute requiring a law license to engage in business of debt adjustment); Williamson v. Lee Optical Co. of Okla. Inc., 348 US 483, 491 (1955) (applying the rational basis test to uphold a statute prohibiting opticians from fitting or duplicating lenses without a prescription from an ophthalmologist or optometrist).
} 
challenging the law to show that the law is not rationally related to any legitimate end. ${ }^{44}$ When laws burdened fundamental rights, however, strict scrutiny would apply under either due process or equal protection. ${ }^{45}$ To survive strict scrutiny, the burden is on the state to show that its action is necessary and/or narrowly tailored to serve a compelling governmental interest. ${ }^{46}$ The third level of scrutiny, intermediate scrutiny, required that government action must serve an important governmental interest and be substantially related to that interest. ${ }^{47}$

Under the Court's fundamental rights jurisprudence, the critical question in most cases was whether an asserted right was fundamental in character so as to trigger strict scrutiny. Building on Meyer, Pierce, and Skinner, the Court in Griswold v. Connecticut recognized a fundamental

44. In its typically deferential form, the burden was on the party challenging the rule to show that the law did not serve any plausible legitimate purpose. Legitimate purposes were broadly conceived and could include post hoc rationalizations. So long as the government could reasonably believe that the law would further those purposes, it did not matter whether there might be less restrictive or burdensome means, or whether the law was substantially over or under inclusive. For an example of this sort of extreme deference, see FCC v. Beach Comms., Inc., 508 U.S. 307 (1993) (upholding statute requiring local franchise for satellite master antenna and television facilities but exempting systems serving buildings under common ownership).

45. See, e.g., Zablocki v. Redhail, 434 U.S. 374 (1978) (applying strict scrutiny to a invalidate law that prevented fathers who were behind in child support obligations from getting married); Moore v. City of East Cleveland, 431 U.S. 494 (1977) (applying strict scrutiny to a zoning ordinance that prevented extended family from living together in single family neighborhood). Strict scrutiny would apply in other contexts as well, including review of government action that employed racial classifications, see, e.g., Palmore v. Sidoti, 466 U.S. 429 (1984) (applying strict scrutiny to invalidate state court judgment removing child from mother's custody because she married a person of a different race), and content-based regulations of speech, see, e.g., Simon \& Schuster, Inc. v. Members of the N.Y. State Crime Victims Bd., 502 U.S. 105 (1991) (applying strict scrutiny to a state "Son of Sam" law requiring convicted criminals' income from works describing their crimes to be deposited in an escrow account for the benefit of their victims and other creditors). The Court's suspect classification and First Amendment jurisprudence are definitely part of the larger trends discussed in this Article, but they are not directly relevant to the Hodes \& Nauser decision and so will not be explored further here.

46. Under strict scrutiny, the government has to satisfy a very heavy burden in order to justify a law. See generally cases cited supra note 45 . There must be convincing evidence to support the governmental interest asserted in support of the laws. More significantly, perhaps, government action would not be necessary or narrowly tailored to those purposes if there were less restrictive or burdensome alternatives or if the action was over or under inclusive. Although the Court tended to use the term "necessary" when dealing with fundamental rights and "narrowly tailored" when dealing with suspect classifications, in practice both terms incorporated less restrictive alternative and over/under inclusiveness analysis.

47. Under equal protection doctrine, intermediate scrutiny applies to sex and gender-based classifications. See, e.g., Craig v. Boren, 429 U.S. 190 (1976) (invalidating an Oklahoma law establishing differential drinking age for males and females). Intermediate scrutiny also applies to classifications affecting nonmarital children. See, e.g., Clark v. Jeter, 486 U.S. 456 (1988) (invalidating a statute requiring nonmarital children to prove paternity before turning six in order to seek child support). Under First Amendment doctrine, intermediate scrutiny applies to content neutral laws regulating speech. See, e.g., Clark v. Cmty. for Creative Non-Violence, 468 U.S. 288 (1984) (applying intermediate scrutiny to uphold a ban on camping in public park as applied to a demonstration using sleeping in a park as a means of protest against homelessness). 
right of privacy associated with marriage, procreation, and the family, invalidating a law prohibiting the use of contraception by married couples. $^{48}$ Griswold relied on the notion that this right was within the penumbras of specific provisions of the Bill of Rights, ${ }^{49}$ perhaps in an effort to link the right to the incorporation doctrine and Carolene Products. In subsequent cases, however, the Court abandoned that approach and simply treated privacy as a nontextual fundamental right.

These subsequent cases took the right of privacy as a given, and the Court addressed particular rights claims by asking whether the claim was sufficiently related to the right so as to fall within its scope. ${ }^{50}$ This approach allowed the Court to expand the right of privacy conceptually by associating particular claims to the underlying concept of privacy rather than by engaging in an independent assessment of whether a particular right was fundamental. It was this kind of analysis that eventually produced Roe v. Wade, in which the Court concluded that a woman's right to control her pregnancy was within the scope of the right of privacy. ${ }^{51}$ During this same period, however, the Court also recognized other, unrelated rights as fundamental and subject to strict scrutiny, including the right to vote ${ }^{52}$ and the right to travel, ${ }^{53}$ often relying on the Equal Protection Clause.

Although the cases established several categories of fundamental rights, most prominently the right of privacy, they did not establish a clear framework for determining whether a right was fundamental. Some of the due process cases connected the recognition of nontextual fundamental rights with the incorporation doctrine. ${ }^{54}$ The equal protection cases often referenced the ways in which particular rights, such as the right to vote,

48. 381 U.S. 479 (1965)

49. See id. at 484-86.

50. See Carey v. Population Servs. Int'1, 431 U.S. 678, 684-85 (1977) (describing the right of privacy as a "cluster of constitutionally protected choices").

51. 410 U.S. 113, 153 (1973) ("This right of privacy, whether it be founded in the Fourteenth Amendment's concept of personal liberty and restrictions upon state action, as we feel it is, or, as the District Court determined, in the Ninth Amendment's reservation of rights to the people, is broad enough to encompass a woman's decision whether or not to terminate her pregnancy.").

52. See Harper v. Va. Bd. of Elections, 383 U.S. 663, 667 (1966) (applying strict scrutiny under the Equal Protection Clause to invalidate a poll tax as a violation of fundamental right to vote); Wesberry v. Sanders, 376 U.S. 1, 18 (1964) (applying strict scrutiny to invalidate use of legislative districts of unequal population as a violation of the fundamental right to vote).

53. Shapiro v. Thompson, 394 U.S. 618, 674 (1969) (applying strict scrutiny to invalidate a state law requiring people to live in the state for one year before they would be eligible for welfare benefits because this "durational residence requirement" burdened the fundamental right to travel in violation of the Equal Protection Clause).

54. This connection was explicit in Griswold v. Connecticut, in which the Court grounded the right to privacy in the penumbras of incorporated bill of rights provisions, such as the First and Fourteenth Amendments. See 381 U.S. 479, 482-85 (1965). 
were preservative of other rights. ${ }^{55}$ In many other cases, as in Roe, the Court expanded the scope of previously recognized rights conceptually. ${ }^{56}$ In the end, however, the decisions largely depended upon the judgment of the Court that a particular right was important enough to be deemed fundamental.

\section{The Right-Specific Approach}

Even as the fundamental rights approach reached its peak, a series of conservative appointments sowed the seeds of its eventual erosion. ${ }^{57}$ As described below, starting in the 1980s and with increasing momentum in the decades that followed, the Supreme Court refashioned its constitutional rights jurisprudence - one right at a time. This rightspecific approach rejected the conceptual expansion of fundamental rights and demanded an independent constitutional pedigree for each asserted right. Under this approach, the Court not only resisted the expansion of fundamental rights doctrine, but also reexamined the foundations of previously determined rights, often restating the doctrine in ways that limited or reduced the protection for those rights.

Insofar as the right-specific approach isolates each claimed right on its own constitutional foundation, the Court also moved away from the comprehensive application of the three levels of ends-means scrutiny, adopting distinctive rules and tests for each kind of recognized right. Although the Court has not completely repudiated the fundamental rights approach and occasionally relies on some of its elements, the right-specific approach has fundamentally reshaped the landscape of rights, including abortion rights.

The core premise of the right-specific approach is that each rights

55. See, e.g., Reynolds v. Sims, 377 U.S. 533, 562 (1964) ("Especially since the right to exercise the franchise in a free and unimpaired manner is preservative of other basic civil and political rights, any alleged infringement of the right of citizens to vote must be carefully and meticulously scrutinized.").

56. See supra note 51.

57. President Nixon appointed Justice Rehnquist in 1972, who became Chief Justice in 1986 on the retirement of Chief Justice Burger. President Reagan appointed Justice O'Connor in 1981 and Justice Scalia in 1986. President George H.W. Bush appointed Justice Kennedy in 1988, Justice Souter in 1990, and Justice Thomas in 1991. Although Justices O'Connor, Kennedy, and Souter, who formed the plurality in Planned Parenthood of Southeastern Pennsylvania v. Casey, 505 U.S. 833 (1992), came to be regarded as moderates, their appointments moved the Court in a more conservative direction. More recently, President George W. Bush appointed Chief Justice Roberts in 2005 and Justice Alito in 2006, and President Trump appointed Justice Gorsuch in 2017 and Justice Kavanaugh in 2018. Although Presidents Clinton and Obama appointed some liberal Justices, the current Court has a majority of five staunchly conservative justices. 
claim must rest on its own right-specific constitutional foundation. ${ }^{58}$ In keeping with this approach, the Court would define a claimed right narrowly and resist the extension of previously recognized rights, such as the right of privacy, by analogy. If a particular claim is not within the scope of previously recognized rights, then its proponents must identify an independent constitutional basis for protecting the right. Although the Due Process Clause provided a constitutional foundation for the protection of substantive liberties, under the right-specific approach it applied only if the particular rights claim is deeply rooted in our traditions and collective conscience or implicit in the concept of ordered liberty. ${ }^{59}$

The Court deployed this type of analysis in Bowers v. Hardwick, which declined to expand the right of privacy so as to recognize a right of consensual intimacy between same-sex couples in the privacy of their home. ${ }^{60}$ The Court began by characterizing the issue in the case as "whether the Federal Constitution confers a fundamental right upon homosexuals to engage in sodomy and hence invalidates the laws of the many States that still make such conduct illegal and have done so for a very long time." 61 The Court then concluded that "none of the rights announced in [the Court's privacy] cases bears any resemblance to the claimed constitutional right of homosexuals to engage in acts of sodomy" and that " $[n]$ o connection between family, marriage, or procreation on the one hand and homosexual activity on the other has been demonstrated." Finally, the Court had no difficulty concluding that, given the history of criminal proscriptions against sodomy, "to claim that a right to engage in such conduct is 'deeply rooted in this Nation's history and tradition' or 'implicit in the concept of ordered liberty' is, at best, facetious."

Chief Justice Rehnquist purported to formalize this approach in Washington v. Glucksberg, which upheld state laws criminalizing physician-assisted suicide. ${ }^{64}$ His opinion for the Court began with the following statement of the law:

Our established method of substantive-due-process analysis has two

58. See, e.g., Washington v. Glucksberg, 521 U.S. 702 (1997) (declining to recognize the right to physician assisted suicide).

59. In addition, the Court often relied on an historical analysis when deciding whether a right was implicit in the concept of ordered liberty, reasoning that the lack of historical protections for a right was evidence that the right was not essential to ordered liberty. This sort of analysis made it especially difficult to successfully assert new rights.

60. 478 U.S. 186, 195-96 (1986).

61. Id. at 190 .

62. Id. at $190-91$.

63. Id. at 194.

64. 521 U.S. 702, 792 (1997). 
primary features: First, we have regularly observed that the Due Process Clause specially protects those fundamental rights and liberties which are, objectively, deeply rooted in this Nation's history and tradition, and implicit in the concept of ordered liberty, such that "neither liberty nor justice would exist if they were sacrificed. Second, we have required in substantive-due-process cases a careful description of the asserted fundamental liberty interest. ${ }^{65}$

In keeping with this approach, the Court rejected the characterization of the right at issue as the "right to die," describing it instead as "a right to commit suicide which itself includes a right to assistance in doing so."66

It is worth emphasizing that the narrow definition of the right at issue is critical to the rejection of rights under this analysis. For example, the right to same-sex sodomy is neither connected to privacy protections nor independently recognizable under the test for fundamental rights, but the right to intimacy between consenting adults in the privacy of the home might be. ${ }^{67}$ Likewise, the right to die is much more likely to be implicit in the concept of ordered liberty than the right to physician-assisted suicide. ${ }^{68}$

The Bowers/Glucksberg doctrine did not completely prevent the expansion of the right to privacy. In Cruzan v. Director, Missouri Department of Health, the Court concluded that the right to refuse unwanted medical treatment, as a component of the right of bodily integrity, met the deeply rooted and implicit in ordered liberty test for substantive due process. ${ }^{69}$ More fundamentally, in some other cases the Court continued to define the right at issue broadly and explicitly rejected the narrow conception of individual rights claims. Most directly, in Lawrence v. Texas,${ }^{70}$ the Court overruled Bowers, explicitly criticizing the prior decision's characterization of the right. ${ }^{71}$ The Court used the same sort of reasoning to recognize the right of same-sex couples to marry in

65. Id. at 720-21 (internal quotation marks and citations omitted).

66. Id. at 723 .

67. Compare Bowers, 478 U.S. at 190-91 (explaining that there is no fundamental right to samesex sodomy), with Griswold v. Connecticut, 381 U.S. 479, 484-86 (1965) (holding that there is a right to privacy in intimate decisions in the marital bedroom).

68. Compare Glucksberg, 521 U.S. 702 (rejecting the right to physician assisted suicide), with Cruzan v. Dir., Mo. Dep't of Health, 497 U.S. 261 (1990) (recognizing the right to refuse medical treatment).

69. 497 U.S. 261, 269-70, 281-82 (1990).

70. 539 U.S. 558, 578 (2003) (concluding that due process protects the right of adult same-sex couples to consensual sexual intimacy in the privacy of the home).

71. See id. at 567 (concluding that the Bowers Court's characterization of the right at issue "discloses the Court's own failure to appreciate the extent of the liberty at stake" and that "[t]o say that the issue in Bowers was simply the right to engage in certain sexual conduct demeans the claim the individual put forward, just as it would demean a married couple were it to be said marriage is simply about the right to have sexual intercourse"). 
Obergefell v. Hodges. ${ }^{72}$

During this period, the Court also reexamined the foundations of some previously recognized fundamental rights. Although the result of this reexamination seldom resulted in a complete reversal of prior cases, it often meant that the Court construed the right more narrowly or adopted a less protective test for the right. These developments had particular significance for cases involving fundamental rights under the Equal Protection Clause. In Saenz v. Roe ${ }^{73}$ for example, the Court held that the right to travel arises under the Fourteenth Amendment's Citizenship and Privileges and Immunities Clauses rather than the Equal Protection Clause, adopting a narrow per se rule against treating new residents less favorably than long-term residents rather than a broad application of strict scrutiny for laws that burden interstate movement. ${ }^{74}$ Similarly, in Crawford v. Marion County Election Board, ${ }^{75}$ the Court upheld a voter ID law, declining to apply strict scrutiny in the absence of proof that the law imposed a severe burden on the right to vote. ${ }^{76}$

The right-specific approach led to fundamental changes in the Court's abortion rights jurisprudence. The plurality in Planned Parenthood of Southeastern Pennsylvania v. Casey reaffirmed that the right of privacy encompassed abortion rights and the Roe v. Wade's "core holding,"77 but it pointedly declined to characterize abortion rights as fundamental ${ }^{78}$ and replaced strict scrutiny with a weaker right-specific standard, the "undue

72. See 135 S. Ct. 2584, 2602 (2015) (noting that prior cases did not narrowly define the right, such as the "right to interracial marriage" or the "right of inmates to marry," but more broadly characterized the right as the "right to marry," which the Court applied here).

73. 526 U.S. 489, 510 (1999) (invalidating a state law limiting welfare benefits for new residents).

74. See id. at 499-504 (re-examining foundations of the three components of the right to travel and concluding that the right of new residents to become citizens and receive equal treatment derives from the Citizenship and Privileges and Immunities Clauses of the Fourteenth Amendment). Although this analysis preserved the result of Shapiro v. Thompson, 394 U.S. 618 (1969), it limits the scope of the right to travel in other contexts. Saenz, 526 U.S. at 506-07.

75. 553 U.S. 181 (2008)

76. Id. at 202-04. The plurality opinion adopted a sliding-scale test under which the level of scrutiny rises with the extent of the burden on the right to vote. See id. at 190-91 (plurality opinion) (describing application of the "balancing approach" under which the Court must "weigh the asserted injury to the right to vote against the "precise interests put forward by the State as justifications for the burden imposed by its rule"” (quoting Burdick v. Takushi, 504 U.S. 428, 443 (1992))). The concurring Justices rejected that test in favor of a two-tiered analysis under which the rational basis test applied unless the burden on the right to vote is severe, in which case strict scrutiny applies. See id. at 20405 (Scalia, J., concurring) ("To evaluate a law respecting the right to vote . . . we use the approach set out in Burdick v. Takushi. This calls for application of a deferential 'important regulatory interests' standard for nonsevere, nondiscriminatory restrictions, reserving strict scrutiny for laws that severely restrict the right to vote." (citation omitted) (quoting Burdick, 504 U.S. 428, 433-34)).

77. 505 U.S. 833,853 (1992).

78. See, e.g., id. ("It was this dimension of personal liberty that Roe sought to protect, and its holding invoked the reasoning and the tradition of the precedents we have discussed, granting protection to substantive liberties of the person."). 
burden" test. ${ }^{79}$ In the aftermath of Casey, a majority of the Court appeared to embrace the undue burden test, but subsequent decisions sent mixed signals regarding the test's application. ${ }^{80}$ Most recently, Whole Woman's Health $v$. Hellerstedt appeared to affirm a less deferential version of the undue burden test, but only seven Justices decided the case, as Justice Scalia had passed and Justice Kagan recused herself. ${ }^{81}$

Since Whole Woman's Health, Justice Scalia has been replaced by Justice Gorsuch ${ }^{82}$ and Justice Kennedy-who represented the crucial vote in Whole Woman's Health and other important privacy rights cases-has been replaced by Justice Kavanaugh. ${ }^{83}$ It is widely assumed that both Justice Gorsuch and Justice Kavanaugh would vote to overturn Roe v. Wade, although Justices have been known to surprise on this issue in the past. $^{84}$ In any event, the future of federal protection for abortion rights is in doubt.

\section{The Relationship Between Federal and State Constitutional Rights}

Federal and state constitutional rights interact in complex ways. Under the Supremacy Clause, state laws are invalid to the extent that they interfere with federal constitutional rights. ${ }^{85}$ Under the original Constitution, however, the Bill of Rights applied only to the national government, ${ }^{86}$ and only a few provisions in Article I, Section 10 protected

79. See id. at 874 ("Only where state regulation imposes an undue burden on a woman's ability to make this decision does the power of the State reach into the heart of the liberty protected by the Due Process Clause."); see also id. at 877 ("A finding of an undue burden is a shorthand for the conclusion that a state regulation has the purpose or effect of placing a substantial obstacle in the path of a woman seeking an abortion of a nonviable fetus.").

80. Compare Stenberg v. Carhart, 530 U.S. 914, 922 (2000) (invalidating a Nebraska statute prohibiting "partial birth" abortions), with Gonzales v. Carhart, 550 U.S. 124, 132-33 (2007) (distinguishing Stenberg and upholding a federal statute limiting certain partial birth abortions). For further discussion of these cases, see infra notes 145-51 and accompanying text.

81. 136 S. Ct. 2292 (2016) (invalidating a Texas law requiring physicians performing abortions to have admitting privileges at nearby hospitals and requiring facilities to meet requirements for surgical centers).

82. Nina Totenberg, Senate Confirms Gorsuch to Supreme Court, NPR (Apr. 7, 2017, 5:00 AM), https://www.npr.org/2017/04/07/522902281/senate-confirms-gorsuch-to-supreme-court [https:// perma.cc/M8Q2-FFN8].

83. Tessa Berenson, Inside Brett Kavanaugh's First Term on the Supreme Court, TIME (June 28, 2019), https://time.com/longform/brett-kavanaugh-supreme-court-first-term/ [https://perma.cc/9PMD $-5 \mathrm{QXJ}]$.

84. Indeed, the three Justices in the Casey plurality (Justices Kennedy, O'Connor, and Souter) were all appointed by Republican Presidents who sought to overturn Roe.

85. U.S. CONST. art. VI, cl. 2.

86. Barron v. City of Baltimore, 32 U.S. (7 Pet.) 243, 250 (1833) (holding the Bill of Rights did not apply to the states). 
individual rights against states. ${ }^{87}$ This arrangement rested in part on the assumption that state constitutions would serve as the primary protectors of individual rights, but was also driven by the concerns of slave states that federal rights protections might be wielded against states to prohibit slavery. ${ }^{88}$

In the aftermath of the Civil War, the Thirteenth, Fourteenth, and Fifteenth Amendments established federal constitutional protections for certain individual rights against states. The Supreme Court construed these protections narrowly in the Civil Rights Cases $^{89}$ and the SlaughterHouse Cases,${ }^{90}$ but the Court changed course during the Lochner era. ${ }^{91}$ By the end of the twentieth century, the Court had recognized a broad array of federal individual rights protections against the states.

State courts are constitutionally obligated to apply these rights to their own governments. ${ }^{92}$ In this sense, federal constitutional rights represent a floor - the minimum level of constitutional protections for those rights. States must respect these rights even if their own constitutions offer no protection for similar rights. Thus, for example, Kansas must respect the right of same-sex couples to marry ${ }^{93}$ notwithstanding the Kansas Constitution's explicit prohibition on that right. ${ }^{94}$ But these constitutional rights do not represent a ceiling. The states are free to afford greater protections for constitutional rights than the federal constitutional minimum, provided that they do not violate some other constitutional provision. ${ }^{95}$

87. See U.S. CONST. art. I, $\S 10$ (prohibiting states from passing "any Bill of Attainder, ex post facto Law, or Law impairing the Obligation of Contracts").

88. See George Rutherglen, State Action, Private Action, and the Thirteenth Amendment, 94 VA. L. REV. 1367, 1380-91 (2008) (discussing the transformative effects of the Reconstruction amendments on the balance between state and federal power, and the tension surrounding the effects on slavery).

89. 109 U.S. 3, 17 (1883) ("In this connection it is proper to state that civil rights, such as are guarantied [sic] by the Constitution against State aggression, cannot be impaired by the wrongful acts of individuals, unsupported by State authority in the shape of laws, customs, or judicial or executive proceedings."); see also United States v. Cruikshank, 92 U.S. 542, 554 (1875) ("The fourteenth amendment prohibits a State from depriving any person of life, liberty, or property, without due process of law; but this adds nothing to the rights of one citizen as against another.").

90. 83 U.S. (16 Wall.) 36 (1873); see also supra notes 20-21 and accompanying text (discussing the Court's reasoning).

91. See supra Section II.A.1.

92. See U.S. CONST. art. VI, cl. 2.

93. See Obergefell v. Hodges, 135 S. Ct. 2584, 2599 (2015).

94. See KAN. CONST. art. 15, § 16(a) ("Marriage shall be constituted by one man and one woman only. All other marriages are declared to be contrary to the public policy of this state and are void.").

95. See, e.g., Trinity Lutheran Church of Columbia, Inc. v. Comer, 137 S. Ct. 2012, 2024 (2017) (concluding the state could not rely on its own constitution's establishment clause to deny a church an otherwise available playground safety grant because that violated the First Amendment's Free 
As a practical matter, during the 1960s and 1970s, most states focused on federal law, finding no need to examine the issues under their own constitution's provisions or choosing to align their own state's constitutional jurisprudence with that of the United States Supreme Court. With the Court's subsequent retrenchment, however, some state supreme courts have shown a willingness to extend protections under their own constitutions to rights that the United States Supreme Court has declined to recognize. ${ }^{96}$ These developments provide context for the Kansas Supreme Court's decision in Hodes \& Nauser.

As the United States Constitution's protections for abortion rights has become increasingly uncertain, the extent to which state constitutions protect that right has taken on greater significance. The plaintiffs in Hodes $\&$ Nauser sought a resolution of this question by expressly declining to rely on federal law when challenging the Unborn Child Protection from Dismemberment Act. ${ }^{97}$ This choice was clearly intended to force the Kansas courts to decide whether the Kansas Constitution protects abortion rights.

\section{B. Unpacking the Hodes \& Nauser Opinion}

The decision in Hodes \& Nauser was much anticipated. The complaint was initially filed in June, 2015, and the district court granted a temporary injunction five days later. ${ }^{98}$ That decision was affirmed by an evenly divided en banc Kansas Court of Appeals in January of 2016, and the Kansas Supreme Court granted review in April of that year. ${ }^{99}$ The Kansas Supreme Court, however, did not issue its decision until three

Exercise Clause); see also PruneYard Shopping Center v. Robins, 447 U.S. 74, 88 (1980) (concluding that recognition of state constitutional right to protest in privately owned shopping center did not violate owner's property rights under the Takings Clause or First Amendment rights).

96. Most prominently, in the aftermath of Bowers, many states relied on their own constitutions to recognize a right to same sex intimacy. See Lawrence v. Texas, 539 U.S. 558, 576 (2003) ("The courts of five different States have declined to follow [Bowers] in interpreting provisions in their own state constitutions parallel to the Due Process Clause of the Fourteenth Amendment." (citing Jegley v. Picado, 80 S.W.3d 332 (Ark. 2002); Powell v. State, 510 S.E.2d 18, 24 (Ga. 1998); Gryczan v. State, 942 P.2d 112 (Mont. 1997); Campbell v. Sundquist, 926 S.W.2d 250 (Tenn. App. 1996); Commonwealth v. Wasson, 842 S.W.2d 487 (Ky. 1992))). Likewise, state courts recognized the right of same-sex couples to marry long before the United States Supreme Court did. See Obergefell, 135 S. Ct. at 2610 (compiling state supreme court decisions recognizing the right of same-sex couple to marry).

97. See Hodes \& Nauser, MDs, P.A. v. Schmidt, 440 P.3d 461, 470 (Kan. 2019) ("[T] he question asserted by the Doctors [is] whether the Kansas Constitution Bill of Rights independently protects a woman's right to decide whether to continue a pregnancy.").

98. Hodes \& Nauser, MDs, P.A. v. Schmidt, No. 2015CV000490, 2015 WL 13065200, at *1 (D. Kan. June 30, 2015).

99. Hodes \& Nauser, MDs, P.A. v. Schmidt, 368 P.3d 667 (Kan. Ct. App. 2016). 
years later, in April of 2019. ${ }^{100}$ The court's opinion was a lengthy one, reflecting the thorough research and careful deliberation that befits such an important question. Nonetheless, the logic of the opinion is straightforward and consists of three basic propositions:

- Section 1 of the Kansas Constitution's Bill of Rights protects the fundamental right to make decisions about parenting and procreation that extend to a woman's decision whether to continue a pregnancy. ${ }^{101}$

- State laws that burden fundamental rights, including a woman's right to make decisions concerning her pregnancy, are invalid unless they can survive strict scrutiny. ${ }^{102}$

- The plaintiffs were likely to succeed on the merits of their claim that the Unborn Child Protection Act burdened a woman's right to make decisions concerning her pregnancy and could not survive strict scrutiny. ${ }^{103}$

Although a general summary highlighting the key elements of the court's reasoning is essential to understanding Hodes \& Nauser's implications for constitutional rights in Kansas, a detailed description of the court's extended discussion of the historical and precedential foundations for its conclusions is not necessary here.

\section{Recognition of Right}

Section 1 of the Kansas Bill of Rights provides that "[a]ll men are possessed of equal and inalienable natural rights, among which are life, liberty, and the pursuit of happiness."104 The Kansas Supreme Court's recognition of a fundamental right is premised on its interpretation of this provision, as encapsulated in the following statement by the court:

Our analysis leads us to the conclusion that section 1 of the Kansas Constitution Bill of Rights acknowledges rights that are distinct from and broader than the United States Constitution and that our framers intended these rights to be judicially protected against governmental action that does not meet constitutional standards. Among the rights is the right of personal autonomy. This right allows a woman to make her own decisions regarding her body, health, family formation, and family life-

100. See Hodes \& Nauser, 440 P.3d 461.

101. Id. at 502-03.

102. Id.

103. Id.

104. KAN. CONST. Bill of Rights $\S 1$ 
decisions that can include whether to continue a pregnancy. ${ }^{105}$

Unpacking this language, it subsumes several key propositions relating to the meaning of section 1 , the role of the courts in enforcing its provisions, and the specific content of the rights protected.

First, the court interpreted section 1 as protecting rights that are "distinct from and broader than" those protected by the United States Constitution. ${ }^{106}$ In particular, as developed by the court, the provision expressly refers to "natural rights," thus linking it to the natural rights philosophy of the eighteenth and nineteenth centuries. ${ }^{107}$ This text and history indicates that these rights pre-exist the constitution and are, thus, inherently nontextual in nature. ${ }^{108}$ It further indicates that the content of these nontextual rights should be derived from the principles of the natural rights philosophy, which the court understood to include "the principle that individuals should be free to make choices about how to conduct their own lives, or, in other words, to exercise personal autonomy."109

Second, the court emphasized that the history of the provision indicated that the Kansas Constitution's framers intended for the judiciary to enforce these rights, rejecting the state's contention that section 1 did not create judicially enforceable rights. ${ }^{110}$ After reviewing the drafting history of section 1 , which provided no clear answers to the question of judicial enforceability, ${ }^{111}$ the court emphasized that many other state constitutions in existence at the time contained similar provisions and that these provisions had been judicially enforced, suggesting that the framers would have assumed that the Kansas Constitution's provisions would also be judicially enforceable. ${ }^{112}$ The court also cited to its own precedents indicating that section 1 recognized judicially enforceable rights. ${ }^{113}$

\footnotetext{
105. Hodes \& Nauser, 440 P.3d at 471.

106. Id.

107. See id. at $472-73$ (discussing influence of natural rights philosophers, including Locke, Hobbes, and Rousseau on the development of state constitutions, including the Kansas Constitution).

108. Id.

109. Id. at 483 .

110. See id. at 473-80 (examining drafting history, judicial enforcement of similar provisions in other state constitutions, and early Kansas Supreme Court decisions indicating that section 1 is judicially enforceable).

111. See id. at 474-75 (describing different versions of section 1 that were considered, and the eventual emergence of language derived from the Declaration of Independence).

112. Id. at 475-76 (observing that "[t]his broad wording of Kansas's section 1, with its unenumerated natural rights guarantee, was not unlike the natural rights guarantees in at least 14 other states' constitutions" and that "[a]pplying these provisions in cases decided before ... the 1859 Wyandotte Convention, the courts in many of these 14 states had enforced unenumerated rights through judicial orders").

113. See id. at 476-78 (discussing, inter alia, Wright v. Noell, 16 Kan. 601, 603 (1876), and Atchison St. Ry. Co. v. Mo. Pac. Ry. Co., 3 P. 284 (Kan. 1884)).
} 
The court then turned to the substantive content of the natural rights that section 1 protects, identifying three overlapping rights - a right to personal autonomy, a right to bodily integrity, and a right to make decisions about parenting and pregnancy. ${ }^{114}$ First, personal autonomy was at the heart of the natural rights philosophy of Locke and others. ${ }^{115}$ Second, the United States Supreme Court had recognized a natural right of personal autonomy. ${ }^{116}$ Third, state supreme courts, including the Kansas Supreme Court, had recognized a natural right of bodily integrity. ${ }^{117}$ Finally, the concepts of liberty and the pursuit of happiness encompassed the right to make decisions about parenting and procreation. ${ }^{118}$

It followed, therefore, that a woman's decision whether to continue her pregnancy is within the scope of section 1 because pregnancy involves a woman's bodily integrity and her right to make decisions about procreation and children. ${ }^{119}$ The court did, however, dispose of a couple of additional points. First, the court concluded that section 1 protects the rights of women as well as men (notwithstanding its language and the exclusion of women from political and economic life at the time of its drafting). ${ }^{120}$ Second, the court rejected the State's argument that territorial statutes criminalizing abortion, which were in effect at the time the state constitution was adopted, demonstrated that section 1 could not have protected abortion rights. ${ }^{121}$

\section{Strict Scrutiny of Laws Burdening Fundamental Rights}

Having determined that section 1 protected a woman's natural right to control her body and determine whether to continue her pregnancy, the question became whether the Unborn Child Protection Act violated that

\footnotetext{
114. Id. at 480-83 (relying on natural rights theory, decisions of other state courts, and United States Supreme Court decisions).

115. Id. at $480-81$.

116. Id. at $481-82$.

117. Id. at $482-83$.

118. Id. at 483 .

119. Id. at $484-86$.

120. Id. at 483-84. A contrary conclusion would, of course, be untenable in today's world, whatever the expectations of the drafters may have been.

121. Id. at 486-91. The court advanced three justifications for this conclusion:

(1) the history of enactment provides no evidence that the legislation reflected the will of the people; (2) these statutes were never tested for constitutionality; and (3) the historical record reflects that those at the Wyandotte Convention, while willing to recognize some rights for women, refused to recognize women as having all the rights that men had. Id. at 486
} 
right. ${ }^{122}$ In resolving this issue, the Kansas Supreme Court first determined that strict scrutiny applied to laws burdening section 1 natural rights, and then concluded that the law was likely to fail strict scrutiny. ${ }^{123}$ In adopting this analysis, the court rejected the United States Supreme Court's current right-specific approach, ${ }^{124}$ instead linking section 1 analysis to the fundamental rights framework that prevailed during the 1960 s and 1970s. ${ }^{125}$

The court offered a number of reasons why the strict scrutiny standard should apply. Most fundamentally, it derived from and reflected the concept of "inalienable" rights as that term was used in Lockean natural rights theory. ${ }^{126}$ Under Locke's theory, even natural rights could be limited by government action either to protect the rights of others or in furtherance of a compelling governmental interest. ${ }^{127}$ The court then linked the requirement of a compelling governmental interest to strict scrutiny, observing that its precedents in cases involving concurrent claims under section 1 and the Fourteenth Amendment had recognized the three levels of ends-means scrutiny (the rational basis test, intermediate scrutiny, and strict scrutiny). ${ }^{128}$ Further, these precedents had applied strict scrutiny to fundamental rights claims, including abortion rights claims. ${ }^{129}$

The court then rejected the undue burden test adopted in Casey, offering several justifications. ${ }^{130}$ First, the undue burden standard has proven difficult to apply and understand because it is internally contradictory $^{131}$ and because the United States Supreme Court has not

122. Id. at 492 .

123. Id. at $493-98,502-03$.

124. Id. at $493-95$.

125. Id. at $496-98$.

126. Id. at $492-93$.

127. Id. ("This means that, as long as an individual remains within her (or his) private domain, she may do as she pleases, provided her "conduct does not encroach upon the rightful domain of others. As long as [her] actions remain within this rightful domain, other persons-including persons calling themselves government officials - should not interfere without a compelling justification." (alteration in original) (quoting Randy E. Barnett, The Proper Scope of the Police Power, 79 NOTRE DAME L. REV. 429, 446 (2004))).

128. See id. at 493 ("The United States Supreme Court and this court have adopted a standard for courts to apply when determining if the government has met its burden of establishing a compelling justification for enactments. The standard is referred to as "strict scrutiny."').

129. Id.

130. See id. at $493-97$.

131. The court observed that the undue burden test tells states that they "cannot act with the purpose of creating obstacles" to a woman's choice, but that they can "act with the purpose of discouraging abortion." Id. at 494 (quoting Erwin Chemerinsky \& Michele Goodwin, Abortion: A Woman's Private Choice, 95 TEX. L. REV. 1189, 1219-20 (2017)). 
clarified its relation to the traditional levels of scrutiny. ${ }^{132}$ Second, the test requires courts to make inherently subjective judgments about the burdens imposed by regulations that impact women of varying circumstances in different ways. ${ }^{133}$ Third, although there were no cases directly on point, the Kansas Supreme Court's precedents indicate that strict scrutiny is the proper standard for fundamental rights claims. ${ }^{134}$

Finally, and most importantly, the court emphasized that strict scrutiny should apply because "it is our obligation to protect (1) the intent of the Wyandotte Convention delegation and voters who ratified the Constitution and (2) the inalienable natural rights of all Kansans today" and "the strict scrutiny test best protects those natural rights that we today hold to be fundamental."135 In this regard, the undue burden test is insufficiently rigorous because it eases the State's burden of proof to establish that a law is narrowly tailored to further the state's interests and does not require the State to establish that its interests are compelling. ${ }^{136}$

\section{Applying Strict Scrutiny}

Having established the applicable constitutional framework, the Kansas Supreme Court considered whether the plaintiffs' constitutional challenge to the Unborn Child Protection Act was likely to succeed on the merits. ${ }^{137}$ As a preliminary matter, the court disposed of the State's argument that the statute was entitled to a presumption of constitutionality. ${ }^{138}$ It then concluded that the lower courts had improperly applied the undue burden test to analyze the claim, but that a remand was unnecessary because the findings and analysis of the lower courts established that the statute could not survive strict scrutiny. ${ }^{139}$

Many Kansas cases have repeated the general proposition that statutes are entitled to a presumption of constitutionality - a mantra that expresses

132. Id. ("At least one author has referred to the Casey standard as "[a] form of intermediate scrutiny." (quoting Richard H. Fallon Jr., Strict Judicial Scrutiny, 54 UCLA L. REV. 1267, 1299 (2007))).

133. Id. at 495 .

134. Id.

135. Id. at 496 .

136. Id. at 497 ("Simply put, the undue burden standard - both as set out in Hellerstedt, and in the concurring opinion, lacks the rigor demanded by the Kansas Constitution for protecting the right of personal autonomy at issue in this case." (citation omitted)). Likewise, the court rejected the dissent's argument that the rational basis test should apply. See id. at 497 ("For similar reasons we also reject the dissent's position that a governmental regulation, such as S.B. 95, is constitutional as long as it is not arbitrary, irrational, or discriminatory and is reasonably related to the common welfare.").

137. Id. at 498 .

138. Id. at 498-99.

139. Id. at $499-500$. 
respect for the legislature as a coequal and politically accountable branch of government and reflects a broad posture of judicial restraint. ${ }^{140}$ On the other hand, many Kansas cases invalidate Kansas statutes without mentioning or applying the presumption. ${ }^{141}$ In Hodes \& Nauser, the court made clear that the applicability of the presumption is a function of the level of scrutiny that applies, rather than a freestanding principle of judicial restraint that applies to all forms of legislative action. ${ }^{142}$ In particular, the presumption is a manifestation of deferential review under the rational basis test and does not apply under strict scrutiny, in which the burden is on the state to show that a law furthers a compelling interest and is necessary and/or narrowly tailored to that end. ${ }^{143}$

The Kansas Supreme Court then concluded that the trial court had abused its discretion by applying the wrong legal standard (the undue burden test), but that the trial court had correctly ruled that the plaintiffs were likely to succeed on the merits. ${ }^{144}$ Insofar as strict scrutiny is a more rigorous standard than the undue burden test, this conclusion is hardly surprising since the likely success of a challenge under strict scrutiny would seem to follow a fortiori from the likely success of a challenge under the undue burden test. Nonetheless, the Kansas Supreme Court examined the findings and conclusions of the lower court to confirm that a remand for reconsideration under the proper test was unnecessary. ${ }^{145}$

The court of appeals plurality concluded that the Unborn Child Protection Act was invalid in light of Stenberg v. Carhart ${ }^{146}$ and Gonzales

140. See, e.g., id. at 498-99 ("[G]enerally, "[a] statute comes before the court cloaked in a presumption of constitutionality and it is the duty of the one attacking the statute to sustain the burden of proof." (alteration in original) (quoting State ex rel. Schneider v. Liggett, 576 P.2d 221, 226 (Kan. 1978))).

141. See, e.g., Dissmeyer v. State, 249 P.3d 444, 449 (Kan. 2011) (invalidating prohibition of certain machines used for gambling as overbroad without mentioning presumption of constitutionality); Darling v. Kan. Water Office, 774 P.2d 941, 944-46 (Kan. 1989) (invalidating a statute that eliminated civil service provisions in violation of substantive and procedural due process without mentioning the presumption of constitutionality).

142. Id. at 673 (observing that when strict scrutiny applies "the burden of proof is shifted from plaintiff to defendant and the ordinary presumption of validity of the statute is reversed" because "government infringement of a fundamental right is inherently suspect" (quoting Farley v. Engelken, 740 P.2d 1058, 1063 (Kan. 1987))).

143. See supra notes $45-46$ and accompanying text. It is less clear, however, whether and how the presumption applies in the context of intermediate scrutiny, the undue burden test, or other tests for the validity of state action burdening constitutional rights. See infra Part III.

144. Hodes \& Nauser, 440 P.3d at 499-500.

145. Id. at 500-01.

146. 530 U.S. 914, 922 (2000) (invalidating a Nebraska statute prohibiting "partial birth" abortions). 
v. Carhart, ${ }^{147}$ both United States Supreme Court decisions. ${ }^{148}$ Like Hodes \& Nauser, those cases involved statutes prohibiting "partial birth" abortions, such as dilation and evacuation (D \& E), the most common and usually the safest method of second trimester abortion, and dilation and extraction (D \& X or intact D \& E). ${ }^{149}$ Stenberg invalidated a Nebraska partial birth abortion law because it did not contain an exception for the life and health of the mother and because it subjected doctors performing such procedures to criminal prosecution under a vague standard that applied to both methods. ${ }^{150}$ Gonzales v. Carhart distinguished Stenberg and upheld the federal Partial-Birth Abortion Ban Act of 2003, which prohibited only the D \& X method, emphasizing that the D \& E method, which is usually the safest method, remained available. ${ }^{151}$

The Kansas Supreme Court agreed with the court of appeals plurality that, taken together, these cases stand for the proposition that "[a] regulation that prevents [a woman] from accessing the safest method of abortion for her places an undue burden on that right."152 The trial court's findings showed that the Unborn Child Protection Act, which prohibits the D \& E method, violates this principle, especially insofar as the state had previously prohibited the D \& X method. ${ }^{153}$ Thus, the Kansas Supreme Court concluded, "even though we would apply what we view as the more demanding strict scrutiny standard for the State to meet, doing so would not change the conclusions reached by the trial court."154

The court thus affirmed the grant of a preliminary injunction and remanded for a trial on the merits, in which the validity of the Unborn Child Protection Act would depend on whether the State can satisfy strict

147. 550 U.S. 124, 132-33, 135 (2007) (distinguishing Stenberg and upholding a federal statute limiting use of "dilation and evacuation" procedures).

148. Hodes \& Nauser, 440 P.3d at 500-01.

149. See Stenberg, 530 U.S. at 925-29; Gonzales, 550 U.S. at 136-40. The term "partial-birth" abortion is a political term coined by right to life advocates and used in the title of most statutes limiting certain late term abortion methods. The medical terms for the abortion procedures involved are "dilation and evacuation" and "dilation and extraction."

150. Stenberg, 530 U.S. at 929-30 ("We conclude that [Nebraska's statute violates the Federal Constitution] for at least two independent reasons. First, the law lacks any exception 'for the preservation of the ... health of the mother.' Second, it 'imposes an undue burden on a woman's ability' to choose a D \& E abortion, thereby unduly burdening the right to choose abortion itself." (alteration in original) (quoting Planned Parenthood of Se. Pa. v. Casey, 505 U.S. 833, 874, 879 (1992))).

151. See 550 U.S. at 164 ("The conclusion that the Act does not impose an undue burden is supported by other considerations. Alternatives are available to the prohibited procedure. As we have noted, the Act does not proscribe D \& E.").

152. Hodes \& Nauser, 440 P.3d at 500.

153. Id.

154. Id. at 501 . 
scrutiny. ${ }^{155}$ In doing so, the court observed that "the State is certainly free to assert any interests it believes compelling and show how [the Act] is narrowly tailored to those interests." 156 The Kansas Supreme Court acknowledged that the trial court had a "heavy task ahead of it," because it would have to "grapple with one of the most divisive issues of our time," "take into account advances in science that have blurred the sharp trimester-based lines used in Roe's strict scrutiny analysis," and maintain "a deep awareness that the outcome of this case could generate a profound and personal consequence for many women." 157

\section{IMPLICATIONS OF HODES \& NAUSER}

As the foregoing discussion makes clear, Hodes \& Nauser decouples the analysis of individual rights in Kansas from the United States Supreme Court's current right-specific doctrine, linking it instead to the fundamental rights framework that prevailed during the 1960s and 1970s. This approach to the analysis has profound implications not only for abortion rights, but also for the recognition of other fundamental rights under section 1 of the Kansas Bill of Rights and for the application of other provisions of the Kansas Bill of Rights.

\section{A. Implications for Abortion Rights}

Insofar as the specific question in Hodes \& Nauser related to abortion rights, the decision has the most direct and immediate impact on abortion rights in Kansas. It is clear that Hodes \& Nauser provides greater protection for abortion rights than the corresponding federal doctrine by (1) creating an independent right that would be unaffected by a United States Supreme Court decision overruling Roe and Casey; ${ }^{158}$ and (2) adopting strict scrutiny, rather than the undue burden test, for laws burdening abortion rights. ${ }^{159}$ Nonetheless, Hodes \& Nauser is less clear about how strict scrutiny should apply or the constitutionality of the state's other abortion regulations.

As an initial matter, Hodes \& Nauser means that constitutional protection for abortion rights in Kansas is not dependent on whether the United States Supreme Court adheres to Roe v. Wade and Planned Parenthood of Southeastern Pennsylvania v. Casey. Given the uncertain

155. Id. at 502-04.

156. Id. at 503 .

157. Id.

158. See id. at $472-80$.

159. Id. at 493-99. 
future of those cases in the wake of recent appointments to the Court, the significance of that result is undeniable. ${ }^{160}$ On the other hand, the recognition of abortion rights under the Kansas Constitution could be reversed by a state constitutional amendment, ${ }^{161}$ in which case, the United States Supreme Court's abortion rights jurisprudence would become the constitutional floor. ${ }^{162}$

Even if Roe and Casey are not overturned, section 1 of the Kansas Bill of Rights will afford greater protection for abortion rights than current federal law because strict scrutiny, rather than the undue burden test, applies to laws that regulate abortions. ${ }^{163}$ Strict scrutiny differs from the undue burden test in four critical ways:

- Burdens That Trigger Protection-Under strict scrutiny, abortion rights protections are triggered by any sort of burden on access to abortion, while the undue burden test is only violated when the state creates a substantial obstacle. ${ }^{164}$

160. At the time of this writing, the Supreme Court had just heard oral argument in Russo v. June Medical Services, which addresses the validity of a Louisiana law that is similar to the one invalidated in Whole Woman's Health v. Hellerstedt. See Amy Howe, Argument Analysis: Justices Grapple with Louisiana Abortion Law (Updated), SCOTUSBLOG (Mar. 4, 2020, 12:28 PM), https://www .scotusblog.com/2020/03/argument-analysis-justices-grapple-with-louisiana-abortion-law/ [https:// perma.cc/D3NS-EMC2] (analyzing oral arguments); see also Gee v. June Med. Servs., LLC, $140 \mathrm{~S}$. Ct. 35 (2019) (mem.) (granting certiorari). The Court's decision in Gee will likely tell us a great deal about the future of abortion rights under the United States Constitution.

161. Thus, abortion opponents have introduced identical resolutions to amend the Kansas Constitution so as to overrule Hodes \& Nauser. See H.R. Con. Res. 5019, 2020 Leg., Reg. Sess. (Kan. 2020) (" $[T]$ he constitution of the state of Kansas does not require government funding of abortion and does not create or secure a right to abortion.”); S. Con. Res. 1613, 2020 Leg., Reg. Sess. (Kan. 2020) (same). Under article 14, section 1 of the Kansas Constitution, such an amendment must be approved by two-thirds of the members of each house and then presented to the voters for approval. KAN. CONST. art. XIV, $\S 1$. The Kansas Constitution imposes no limits on the content of such an amendment (nor could it), which can be used to overturn Kansas Supreme Court decisions or deny the recognition of constitutional rights under the Kansas Constitution.

162. Another proposed amendment, introduced before the Hodes \& Nauser decision, would guarantee equal rights to "every human being from the beginning of the biological development of that human being, including fertilization.” H.R. Con. Res. 5004, 2019 Leg., Reg. Sess. (Kan. 2019); S. Con. Res. 1604, 2019 Leg., Reg. Sess. (Kan. 2019). This amendment, however, could not prevent enforcement of federally recognized abortion rights, because the United States Constitution is "the supreme Law of the Land; ... any Thing in the Constitution or Laws of any State to the Contrary notwithstanding." U.S. CONST. art. VI, cl. 2 (emphasis added).

163. See Hodes \& Nauser, 440 P.3d 461, 496 (Kan. 2019).

164. Whole Woman's Health might be read to mean that, even absent a substantial obstacle, health regulations that serve no purpose other than to make providing abortions more difficult and costly violate the undue burden test. See Meghan Harper, Comment, Making Sense of Whole Woman's Health v. Hellerstedt: The Development of a New Approach to the Undue Burden Standard, 65 U. KAN. L. REV. 757, 759 (2017) (arguing that Whole Woman's Health establishes a "Rational Basis with Bite Balancing Test," under which a court first applies "the more stringent rational basis with bite test and then considers whether the benefits created by the law outweigh any burden the law places on a woman's access to an abortion"). Even if the Supreme Court's new conservative majority does not overrule Roe and Casey, it seems unlikely that it will continue to apply the arguably heightened version of that test applied in Whole Woman's Health. 
- The State's Burden of Proof-When strict scrutiny is triggered, the state must establish that its actions are justified, while the burden of proof under the undue burden test is uncertain at best and may rest on the party challenging the statute. ${ }^{165}$

- The Weight of State Interests That Justify Regulation-Under strict scrutiny, laws burdening abortion rights can be sustained only if they further a compelling governmental interest, while the undue burden test may be satisfied by lesser state interests, depending on the nature of the burden. ${ }^{166}$

- The Close Fit Between the State's Means and Its Ends-Under strict scrutiny, the state must also prove that its regulation of abortion is (a) necessary in the sense that its compelling interest could not be served by less burdensome means and (b) narrowly tailored in the sense that the regulation is not over or under inclusive. ${ }^{167}$

Nonetheless, while the general parameters of strict scrutiny are clear, Hodes \& Nauser offers relatively little guidance on its application. ${ }^{168}$

In particular, it is unclear whether the pre-Casey United States Supreme Court abortion precedents applying strict scrutiny will be controlling under section 1 of the Kansas Bill of Rights. The application of strict scrutiny in Roe produced a "trimester framework" that resulted from the analysis of two state interests that might support laws regulating abortion-protecting the life and health of the pregnant woman and protecting the life of the unborn child. ${ }^{169}$ In the Court's view, the State's interest in protecting the life and health of the pregnant woman did not become compelling until the second trimester, because before that point in the pregnancy having an abortion would be safer than carrying the child to term. ${ }^{170}$ And while the State's interest in protecting the life of an unborn

165. Id. at 761-64.

166. Id.

167. Id.

168. See 440 P.3d at 682 ("In its merits resolution, the trial court will 'adopt an attitude of active and critical analysis,' as it performs its 'searching judicial inquiry.' As it does so, it should remain mindful... [that] '[c]ourts have no power to overturn a law enacted by the legislature within constitutional limitations, even though the law may be unwise, impolitic or unjust." (first quoting Sate ex rel. Schneider v. Liggett, 576 P.2d 221, 227 (Kan. 1978); then quoting Johnson v. California, 543 U.S. 499, 506 (2005); and then quoting Harris v. Shanahan, 387 P.2d 771, 791 (Kan. 1963))).

169. Roe v. Wade, 410 U.S. 113, 162-64 (1973). Roe also noted that a state might ban abortions on the theory that unwanted pregnancies act as a deterrent against extramarital sex, but that no one had advanced that justification for the law in question. Id. at 148 ("It has been argued occasionally that these laws were the product of a Victorian social concern to discourage illicit sexual conduct. Texas, however, does not advance this justification in the present case, and it appears that no court or commentator has taken the argument seriously.").

170. Id. at 163 . 
child existed throughout a pregnancy, that interest did not become compelling until the third trimester, which (at the time of Roe) reflected the point at which an unborn child would be viable outside the mother's womb. ${ }^{171}$ Thus, under Roe, the State could not regulate abortion at all during the first trimester, it could adopt narrowly tailored laws protecting the life and health of the pregnant woman starting with the second trimester, and it could ban abortions to protect unborn children in the third trimester-provided it made exceptions for the life and health of the mother.

In the aftermath of Roe, the Court applied its trimester framework to several different kinds of abortion regulations, including: (1) abortion funding restrictions; (2) medical regulations; (3) informed consent and waiting requirements; (4) third party notification and consent requirements; and (5) limits on postviability abortions.

- Abortion Funding-The Court upheld funding restrictions preventing the use of public moneys for abortions on the theory that the denial of funding did not burden abortion rights so as to trigger strict scrutiny; i.e., the state has no affirmative obligation to facilitate the exercise of abortion rights. ${ }^{172}$

- Medical Regulations-Although the Court upheld some regulation of abortion as a medical procedure, it invalidated regulations that were not necessary or narrowly tailored to the protection of the lives and health of women undergoing the procedure. $^{173}$

- Informed Consent and Waiting Periods-The Court also invalidated "informed consent" laws requiring that doctors give women information designed to discourage them from having an abortion (such as information about fetal development, graphic descriptions of abortion procedures, disputed statements about

171. Id.

172. See, e.g., Harris v. McRae, 448 U.S. 297, 326 (1980); Maher v. Roe, 432 U.S. 464, 479-80 (1977). The Court later relied on Harris and Maher to uphold laws banning the use of any facilities receiving public funds (most hospitals) to perform abortions, see Webster v. Reprod. Health Servs., 492 U.S. 490, 508-10 (1989), and to uphold regulations prohibiting family planning clinics receiving federal funds from discussing abortion, except to discourage it, see Rust v. Sullivan, 500 U.S. 173, 194, 198 (1991).

173. See, e.g., Thornburgh v. Am. Coll. of Obstetricians \& Gynecologists, 476 U.S. 747, 765-66 (1986) (invalidating recordkeeping requirements that the Court found unnecessary and lacking in sufficient assurances of patient confidentiality); City of Akron v. Akron Ctr. for Reprod. Health, Inc., 462 U.S. 416, 432-39 (1983) (invalidating a municipal ordinance requiring abortions after the first trimester to be performed in hospitals because this requirement was not needed to protect women's health); Planned Parenthood of Cent. Mo. v. Danforth, 428 U.S. 52, 79-81 (1976) (upholding general requirements that physicians keep records concerning abortion but invalidating provisions prohibiting saline amniocentesis because they forced physicians and women to use less safe methods). 
health risks of abortions, and information about alternatives (such as adoption)), which are typically accompanied by a waiting period (usually 24 or 48 hours). ${ }^{174}$

- Third Party Notification and/or Consent-Under the Court's preCasey precedents, spousal consent or notice requirements were invalid, ${ }^{175}$ but parental consent requirements could be upheld if they contained a prompt judicial bypass option for minors who can show good cause and exceptions for emergencies. ${ }^{176}$

- Postviability Abortions - In light of Roe's statements concerning the state's compelling interest in protecting the life of the unborn child after the point of viability, many states enacted laws regulating abortions at or near the point of viability, with mixed results. ${ }^{177}$

While Hodes \& Nauser adopted the strict scrutiny test that applied before Casey, it left unclear whether the adoption of strict scrutiny also meant the adoption of the trimester framework or the array of United States Supreme Court precedents applying it.

This uncertainty raises some interesting questions about the application of strict scrutiny to other Kansas laws regulating abortions, which are very restrictive. These regulations include limitations on abortion funding, ${ }^{178}$ stringent recordkeeping and licensure requirements, ${ }^{179}$ informed consent and waiting period requirements, ${ }^{180}$

174. Thornburgh, 476 U.S. at 759-64 (concluding that such laws burdened abortion rights by imposing additional costs on women seeking an abortion and could not survive strict scrutiny); City of Akron, 462 U.S. at 450-52 (same).

175. See Danforth, 428 U.S. at 80-84 (invalidating a statute containing both spousal and parental consent but suggesting that a "properly" drafted parental consent requirement may be upheld).

176. See, e.g., Ohio v. Akron Ctr. for Reprod. Health, 497 U.S. 502, 519 (1990); Planned Parenthood Ass'n of Kan. City v. Ashcroft, 462 U.S. 476, 490-94 (1983); Bellotti v. Baird, 443 U.S. 622, 651 (1979).

177. Compare Thornburgh, 476 U.S. at 765-71 (invalidating (1) recordkeeping requirements related to determination of viability because potential for public disclosure would deter women from obtaining abortions and (2) requirements for care of a potentially viable fetus that did not make exceptions for the life and health of the mother), and Colautti v. Franklin, 439 U.S. 379, 390-401 (1979) (invalidating requirements that physicians determine viability and provide reasonable care for a potentially viable fetus as unconstitutionally vague), with Webster, 492 U.S. at 521-22 (upholding postviability abortion ban that contained exceptions for the life and health of the mother).

178. See KAN. STAT. ANN. §65-6733 (West 2018) (prohibiting, inter alia, expenditure of any funds or allowance of any tax credits for abortions).

179. See id. $\S 65-4 \mathrm{a} 09$ (directing the Secretary of Health and Environment to promulgate regulations for licensure of abortion providers that must at a minimum meet extensive requirements).

180. See id. §65-6709 (imposing extensive information requirements and a 24-hour waiting period). 
parental consent requirements, ${ }^{181}$ limitations on postviability abortions, ${ }^{182}$ and various other restrictions. ${ }^{183}$ Although some of these provisions were likely unconstitutional under the undue burden test, ${ }^{184}$ the adoption of strict scrutiny means that many more are constitutionally vulnerable. ${ }^{185}$ To highlight the questions raised by the application of strict scrutiny under Hodes \& Nauser, I will focus here on two provisions: informed consent and waiting requirements, K.S.A. $\S 65-6709$, and the state's funding restrictions, K.S.A. $§ 65-6733$.

If the Kansas courts follow the pre-Casey precedents, K.S.A. $\S 65-$ 6709 's informed consent and waiting period requirements are invalid, ${ }^{186}$ while K.S.A. §65-6733's funding restrictions would be valid. ${ }^{187}$ On the other hand, it is possible that the court might apply strict scrutiny differently than the pre-Casey United States Supreme Court decisions. Thus, for example, the Kansas courts might recognize additional purposes as sufficiently compelling to sustain some forms of abortion regulation. In particular, the state might assert a compelling interest in ensuring that women's decisions regarding abortion are fully informed and carefully considered in view of the state's interest in protecting life. If so, it is

181. See id. §65-6705 (requiring written consent of parent(s), subject to the availability of a prompt judicial bypass).

182. See id. $\S 65-6703$ (prohibiting postviability abortions unless the abortion is necessary to preserve the life of the woman or prevent a "substantial and irreversible physical impairment of a major bodily function" and specifying that "[n]o condition shall be deemed to exist if it is based on a claim or diagnosis that the woman will engage in conduct that would result in her death or in substantial and irreversible physical impairment of a major bodily function").

183. See, e.g., id. § 65-6721 (prohibiting "partial birth abortions"); id. §§ 65-6722 to -6724 (prohibiting abortions on "pain-capable unborn child[ren]"); id. § 65-6726 (prohibiting abortions based upon the gender of the fetus).

184. In particular, licensure requirements specified by K.S.A. § 65-4a09 and administrative regulations thereunder were likely unconstitutional under Whole Woman's Health, which invalidated a Texas law requiring physicians performing abortions to have admitting privileges at nearby hospitals and requiring facilities to meet requirements for surgical centers. Whole Woman's Health v. Hellerstedt, 136 S. Ct. 2292, 2318-20 (2016). The Kansas provisions, like those in Texas, are a species of what abortion rights advocates refer to as "TRAP laws" (targeted regulation of abortion providers), whose primary purpose and effect is to make it more costly for abortion providers to stay in business and which lack any demonstrable health or safety benefits. See Hope Silberstein, Taking on TRAP Laws: Protecting Abortion Rights Through Property Rights, 2017 U. CHI. LEGAL F. 737, 737-38 (2017). A challenge to the Kansas provisions is currently pending in the Kansas Court of Appeals. See Hodes \& Nauser, MDs, P.A. v. Norman, No. 19-121046-A (Kan. Ct. App. filed Apr. 17, 2019).

185. See, e.g., Tr. Women Found. v. Bennett, No. 19-121693-A (Kan. Ct. App. filed Aug. 19, 2019) (appealing trial court order denying preliminary injunction in challenge to statutory requirement that medication abortions must be administered by physicians and thereby preventing use of telemedicine).

186. See supra note 174 and accompanying text. Casey overruled those decisions, concluding that such requirements did not impose an undue burden because the ultimate decision whether to have an abortion remained with the pregnant woman. See Planned Parenthood of Se. Pa. v. Casey, 505 U.S. 833, 881-87 (1992).

187. See supra note 172 and accompanying text. 
possible that K.S.A. § 65-6709 could survive strict scrutiny.

Conversely, it is also possible that the Kansas courts would reject the United States Supreme Court decisions upholding abortion funding restrictions, such as Maher v. Roe ${ }^{188}$ Harris v. McRae, ${ }^{189}$ and Webster v. Reproductive Health Services. ${ }^{190}$ Maher, Harris, and Webster rest on the premise that the denial of funding did not impose any burdens on the exercise of abortion rights because the government is not the cause of a woman's inability to pay for an abortion and the government has no affirmative duty to enable the exercise of constitutional rights. ${ }^{191}$ A number of commentators have criticized this reasoning, which is symptomatic of the broader problem of "unconstitutional conditions" in which the government conditions a benefit it need not provide on the relinquishment of constitutional rights. ${ }^{192}$ The Kansas Supreme Court might reject this analysis, concluding instead that the exclusion of abortion procedures from otherwise broadly available funding for medical treatment or facilities has the effect of burdening the exercise of abortion rights so as to trigger strict scrutiny.

In sum, while Hodes \& Nauser adopts strict scrutiny as the applicable standard, that standard might be applied more or less aggressively, so as to replicate the pre-Casey United States Supreme Court doctrine, provide somewhat less protection to abortion rights, or provide even more protections than the pre-Casey decisions. One thing that is certain, however, is that we may expect constitutional challenges to many Kansas statutes regulating abortion. ${ }^{193}$

188. 432 U.S. 464, 480 (1977) (upholding a ban on Medicaid funding for abortions except to save the life and health of the mother).

189. 448 U.S. 297, 326 (1980) (upholding a ban on Medicaid funding for abortions except to save the life and health of the mother).

190. 492 U.S. 490, 509, 512 (1989) (relying on Harris and Maher to uphold a ban on abortions in any facility receiving public funding).

191. See, e.g., Harris, 448 U.S. at 316 ("[A]lthough government may not place obstacles in the path of a woman's exercise of her freedom of choice, it need not remove those not of its own creation.").

192. See, e.g., Kathleen M. Sullivan, Unconstitutional Conditions, 102 HARV. L. REV. 1413, 1440 (1989) (observing that in the abortion funding cases the Court "wholly ignores the question whether the selective subsidy program will deter women from having abortions in the first place - that is, whether it makes childbirth an option that poor women cannot refuse and thereby 'coerces' reproductive choice" and "assumes without explanation that the baseline from which to measure any penalty is no funding for abortion, rather than funding for all medical needs including those related to reproduction").

193. Of course, if Hodes \& Nauser is reversed by constitutional amendment, strict scrutiny will no longer apply. Nonetheless, many of the current Kansas statutes may be vulnerable under the undue burden test-as reflected in the lower court's decision in Hodes \& Nauser itself. See supra note 184, discussing pending challenges to Kansas statutes. 


\section{B. Implications for Other Section 1 Rights}

Hodes \& Nauser also has important implications for other kinds of rights that section 1 may protect. Broadly speaking, these rights include both other components of "personal autonomy" and rights that may be protected by other language in section 1 itself. These implications have already begun to manifest themselves in multiple briefs to the Kansas appellate courts that rely on Hodes \& Nauser to claim special protection for particular rights under section 1 .

\section{Personal Autonomy}

The language and reasoning of Hodes \& Nauser indicate that the "inalienable natural rights" protected under section 1 are rooted in the principle of personal autonomy. ${ }^{194}$ This principle is potentially very broad and may encompass a wide array of interests that are central to people's ability to control their own lives. In light of the court's analysis, the recognition of such rights would not depend on the specific understanding of the framers and ratifiers of the Kansas Constitution, but rather upon a broader analysis of the philosophical, historical, and jurisprudential foundations of the right.

Most clearly, the court in Hodes \& Nauser held that section 1 protects the personal autonomy to make decisions concerning "one's physical health, family formation, and family life." ${ }^{\prime 195}$ These rights, which had previously received protection through the United States Supreme Court's right of privacy decisions, ${ }^{196}$ are now subject to the independent and potentially broader protections afforded by section 1 of the Kansas Bill of Rights. In addition, the court's conceptual analysis of natural rights may facilitate the recognition of other nontextual rights. Two United States Supreme Court decisions, Cruzan v. Director, Missouri Department of Health ${ }^{197}$ and Washington $v$. Glucksberg, ${ }^{198}$ highlight the significance of this point.

In Cruzan, the Court recognized that the right to refuse medical treatment is so connected to the right of bodily integrity as to be within the

\footnotetext{
194. Hodes \& Nauser, MDs, P.A. v. Schmidt, 440 P.3d 461, 484-87 (Kan. 2019) (focusing its discussion on the Kansas Bill of Rights "inalienable natural rights" language in the context of a woman's "personal autonomy").

195. Id. at 483 .

196. See Planned Parenthood of Se. Pa. v. Casey, 505 U.S. 833, 896 (1992).

197. 497 U.S. 261 (1990).

198. 521 U.S. 702 (1997).
} 
liberties protected by due process. ${ }^{199}$ Nonetheless, the Court applied a balancing test rather than strict scrutiny to uphold a state law requiring clear and convincing evidence of an incompetent patient's intent to refuse treatment. ${ }^{200}$ The result in Cruzan might be different under Hodes \& Nauser because burdens on the right to refuse medical treatment, which are clearly encompassed in the concept of "physical health," would likely be subject to strict scrutiny rather than a balancing test. ${ }^{201}$ While the state clearly has a compelling governmental interest in ensuring that the refusal of life sustaining treatments in fact reflects the wishes of an incompetent patient, it is less clear that requiring clear and convincing evidence is a narrowly tailored means of furthering that interest.

In Glucksberg, the Court declined to recognize a "right to die," characterizing the claim in that case as asserting the right to physicianassisted suicide. ${ }^{202}$ Because a right to physician-assisted suicide was neither deeply rooted in our nation's history nor implicit in the concept of ordered liberty, ${ }^{203}$ the Court declined to apply strict scrutiny, instead applying the rational basis test to uphold the law. ${ }^{204}$ This result was largely the product of the Court's narrow definition of the right at issue, an approach that Hodes \& Nauser rejected. ${ }^{205}$ Using a broader conceptual approach to natural rights under section 1, the Kansas courts might be more inclined to treat the right to die as within the scope of personal autonomy and the right to make decisions concerning one's physical

199. 497 U.S. at 278 ("The principle that a competent person has a constitutionally protected liberty interest in refusing unwanted medical treatment may be inferred from our prior decisions.").

200. Id. at $279,286-87$ ("[W] $[\mathrm{W}$ ther respondent's constitutional rights have been violated must be determined by balancing his liberty interests against the relevant state interests." (quoting Youngberg v. Romeo, 457 U.S. 307, 321 (1982))).

201. In this regard, Hodes \& Nauser's reasons for applying strict scrutiny to laws burdening abortions would apply equally to any fundamental right protected by section 1 of the Kansas Bill of Rights. See supra notes 126-36 and accompanying text (discussing court's reasons for applying strict scrutiny in Hodes \& Nauser).

202. 521 U.S. at $722-23$ (rejecting the lower court's characterization of the issue as whether there was a right to die and instead characterizing the question as "whether the 'liberty' specially protected by the Due Process Clause includes a right to commit suicide which itself includes a right to assistance in doing so").

203. Id. at 728 ("The history of the law's treatment of assisted suicide in this country has been and continues to be one of the rejection of nearly all efforts to permit it. That being the case, our decisions lead us to conclude that the asserted 'right' to assistance in committing suicide is not a fundamental liberty interest protected by the Due Process Clause.").

204. Id. at 728-36 (concluding that the ban was reasonably related to the state's legitimate interest in protecting life, policing the ethics of the medical profession, protecting vulnerable persons, and avoiding the slippery slope to euthanasia).

205. Hodes \& Nauser MDs, P.A. v. Schmidt, 440 P.3d 461, 484-86 (Kan. 2019) (defining the right at issue broadly in terms of "bodily autonomy"). 
health. ${ }^{206}$

In addition to broad construction and application of the rights explicitly recognized in Hodes \& Nauser, the court's analysis might also invite recognition of additional rights related to personal autonomy. It is much easier to explain why a broadly conceived right is conceptually linked to personal autonomy than it would be to show that a specific right, narrowly defined, is deeply rooted in our traditions or implicit in the concept of ordered liberty. ${ }^{207}$ Among other things, fundamental rights under section 1 might include rights that have been recognized under federal law as among the privileges and immunities of state citizenship, including freedom of contract, the right to own property, and the pursuit of a calling. ${ }^{208}$ Other rights, such as the right to vote, might also be considered fundamental for purposes of section $1 .{ }^{209}$

At this point, it is difficult to predict the full range of rights that might be derived from the concept of personal autonomy, but two claims have already been advanced in several briefs to the Kansas courts. All of these briefs were submitted by the Kansas Appellate Defender's Office, which argued that criminal convictions should be overturned because statutory provisions limiting defenses violated section 1 of the Kansas Bill of

206. For similar reasons, Kansas courts might decline to follow Abigail Alliance for Better Access to Developmental Drugs v. von Eschenbach, in which the D.C. Circuit declined to recognize a right of terminally ill patients to have access to experimental drugs. 495 F.3d 695, 713 (D.C. Cir. 2007) (en banc). See also Raich v. Gonzales, 500 F.3d 850, 864, 866-87 (9th Cir. 2007) (rejecting the claim that "the Due Process Clause embraces a right to make a life-shaping decision on a physician's advice to use medical marijuana").

207. See supra Section II.A.2 (discussing the implications of the right-specific approach for the recognition of rights).

208. See Corfield v. Coryell, 6 F. Cas. 546, 551-52 (E.D. Pa. Cir. Ct. 1823) (recognizing the following rights: "Protection by the government; the enjoyment of life and liberty, with the right to acquire and possess property of every kind, and to pursue and obtain happiness and safety; subject nevertheless to such restraints as the government may justly prescribe for the general good of the whole. The right of a citizen of one state to pass through, or to reside in any other state, for purposes of trade, agriculture, professional pursuits, or otherwise; to claim the benefit of the writ of habeas corpus; to institute and maintain actions of any kind in the courts of the state; to take, hold and dispose of property, either real or personal; and an exemption from higher taxes or impositions than are paid by the other citizens of the state; may be mentioned as some of the particular privileges and immunities of citizens, which are clearly embraced by the general description of privileges deemed to be fundamental: to which may be added, the elective franchise, as regulated and established by the laws or constitution of the state in which it is to be exercised.").

209. Although the right to vote is not directly related to personal autonomy, the United States Supreme Court has called it a fundamental right because it is preservative of other rights. See, e.g., Reynolds v. Sims, 377 U.S. 533, 562 (1964) ("Especially since the right to exercise the franchise in a free and unimpaired manner is preservative of other basic civil and political rights, any alleged infringement of the right of citizens to vote must be carefully and meticulously scrutinized."). A right that is preservative of personal autonomy might be sufficiently linked to it so as to bring the right within the scope of section 1. 
Rights. ${ }^{210}$ First, in State v. Phillips ${ }^{211}$ and State v. Milo, ${ }^{212}$ the defendant relied on Hodes \& Nauser to argue that statutory limitations on the right of self-defense violated section $1 .^{213}$ Second, in State v. Genson, ${ }^{214}$ the defendant relied on Hodes \& Nauser to argue that statutory limitations on the insanity defense violated section $1 .{ }^{215}$

\section{Additional Section 1 Protections}

Although the Kansas Supreme Court's opinion in Hodes \& Nauser focused on the concept of "inalienable natural rights," 216 section 1 also contains other language that might be the source of enhanced protection for rights. Specifically, section 1 declares that all people "are possessed of equal and inalienable natural rights" and explicitly lists "life, liberty, and the pursuit of happiness" as among those rights. ${ }^{217}$ The court's conclusion that section 1 was intended to provide independent and greater protection than the United States Constitution may suggest that section 1 could be a source of independent equal protection rights and/or protections for the right to life under section 1 that could be greater than their federal counterparts.

\section{a. Equal Protection}

In prior decisions, the Kansas Supreme Court has described section 1 's reference to equal rights as the Kansas Constitution's “equal protection

210. See Brief of Appellant at 16-17, State v. Phillips, No. 19-121075-S (Kan. filed Nov. 27, 2019), 2019 WL 6448485; Brief of Appellant at 7-10, State v. Milo, No. 19-121076-S (Kan. filed Nov. 6, 2019), 2019 WL 5866034; Brief of Appellant at 17-21, State v. Genson, No. 19-121014-A (Kan. Ct. App. filed Aug. 12, 2019), 2019 WL 3946884. The Kansas Appellate Defenders Office has also relied on Hodes \& Nauser to argue that statutory provisions violated rights protected by other provisions of the Kansas Bill of Rights. See, e.g., infra notes 230-35 and accompanying text (Batson claims); infra note 286 and accompanying text (right to keep and bear arms under section 4 of the Kansas Bill of Rights).

211. No. 19-121075-S (Kan. filed Apr. 23, 2019).

212. No. 19-121076-S (Kan. filed Feb. 13, 2019).

213. See Brief of Appellant at 16-17, State v. Phillips, No. 19-121075-S (Kan. filed Nov. 27, 2019), 2019 WL 6448485; Brief of Appellant at 7-10, State v. Milo, No. 19-121076-S (Kan. filed Nov. 6, 2019), 2019 WL 5866034.

214. No. 19-121014-A (Kan. Ct. App. filed Apr. 8, 2019).

215. See Brief of Appellant at 17-21, State v. Genson, No. 19-121014-A (Kan. Ct. App. filed Aug. 12, 2019), 2019 WL 3946884. This brief also used Hodes \& Nauser to argue that the state's treatment of the insanity defense violated the right to a jury under section 5 of the Kansas Bill of Rights. See id. at 9-17. For further discussion of the implications of Hodes \& Nauser for the right to a jury trial, see infra note 266-81 and accompanying text.

216. See Hodes \& Nauser MDs, P.A. v. Schmidt, 440 P.3d 461, 466 (Kan. 2019) (opening the opinion by quoting section 1 of the Kansas Constitution Bill of Rights).

217. KAN. CONST. Bill of Rights $\S 1$ (emphases added). 
clause."218 These cases generally aligned equal protection analysis under section 1 with the United States Supreme Court's equal protection doctrine. ${ }^{219}$ Under this framework, the courts apply different levels of scrutiny depending on the nature of a classification on which state action is based. ${ }^{220}$ The rational basis test applies to ordinary classifications, ${ }^{221}$ intermediate scrutiny applies to sex or gender based classifications, ${ }^{222}$ and strict scrutiny applies to classifications based on race or national origin. ${ }^{223}$

Insofar as Hodes \& Nauser declared that section 1 was intended to provide independent and greater protection of individual rights than the United States Constitution, it may signal a readiness to provide greater protection for those adversely affected by arguably discriminatory laws

218. See, e.g., Bair v. Peck, 811 P.2d 1176, 1182, 1191 (Kan. 1991) (concluding, on certification from the federal district court, that statutory provision eliminating health care providers' vicarious liability for negligence of employees did not violate sections 1, 5, or 18 of the Kansas Bill of Rights).

219. See, e.g., id. at 1182-83. Section 2 of the Kansas Bill of Rights also contains equal protection language: "All political power is inherent in the people, and all free governments are founded on their authority, and are instituted for their equal protection and benefit." KAN. CONST. Bill of Rights $\S 2$. See also Farley v. Engelken, 740 P.2d 1058, 1061 (Kan. 1987) (stating that while sections 1 and 2 of the Kansas Bill of Rights "are given much the same effect as the clauses of the Fourteenth Amendment relating to due process and equal protection of the law," section 2 "has been construed as referring only to political privileges and not to property rights," so that "[w]hen an equal protection challenge is raised involving individual personal or property rights, not political rights, the proper constitutional section to be considered is section 1").

220. See generally Richard E. Levy, Political Process and Individual Fairness Rationales in the U.S. Supreme Court's Suspect Classification Jurisprudence, 50 WASHBURN L.J. 33, 34-38 (2010) (summarizing the various levels of scrutiny and their applicability). In some cases, the United States Supreme Court has elevated scrutiny because a classification burdens a fundamental right. See supra notes 36-38, 45 and accompanying text. However, that line of cases is likely subsumed in Hodes \& Nauser's analysis of inalienable natural rights analysis.

221. See, e.g., FCC v. Beach Commc'ns, Inc., 508 U.S. 307, 313 (1993) (applying rational basis scrutiny to a "classification that neither proceeds along suspect lines nor infringes fundamental constitutional rights" and upholding the regulation "if there is any reasonably conceived state of facts that could provide a rational basis for the classification"). Although this test is ordinarily very deferential, as in Beach Communications, in some cases the Court has applied a more rigorous form of the rational basis test to invalidate laws that reflect animus towards a politically unpopular group. See, e.g., Romer v. Evans, 517 U.S. 620 (1996) (invalidating a state constitutional amendment prohibiting laws banning discrimination based on sexual orientation); City of Cleburne v. Cleburne Living Ctr., 473 U.S. 432 (1985) (invalidating denial of zoning variance to group home for adults with developmental disabilities). This form of rational basis scrutiny is often referred to as "rational basis with bite." See infra note 225 .

222. See, e.g., Nguyen v. INS, 533 U.S. 53 (2001) (applying intermediate scrutiny to uphold statute requiring unwed U.S. fathers, but not U.S. mothers, to have established relationship with child born outside the U.S. in order to confer citizenship); United States v. Virginia, 518 U.S. 515 (1996) (applying intermediate scrutiny to invalidate males only admissions policy at Virginia Military Institute).

223. See, e.g., Johnson v. California, 543 U.S. 499 (2005) (holding that strict scrutiny applied to prison regulation providing for new prisoners to be placed temporarily in cells with occupants of the same race); Richmond v. J.A. Croson Co., 488 U.S. 469, 493-511 (1989) (applying strict scrutiny to race-based affirmative action programs). 
than is currently available under federal doctrine. ${ }^{224}$ This enhanced protection might take various forms, such as more rigorous application of the rational basis test to ordinary classifications, ${ }^{225}$ the application of heightened scrutiny to additional classifications (such as disability, age, poverty, or sexual orientation), ${ }^{226}$ or more rigorous scrutiny of laws implicating suspect (or quasi-suspect) classifications. ${ }^{227}$

One area of potential significance could be the treatment of disparate impact claims; i.e., challenges to facially neutral actions that disproportionately burden minorities or women. Under federal equal protection doctrine, such laws or policies do not trigger elevated forms of scrutiny unless the party challenging the law can prove intentional discrimination. ${ }^{228}$ This rule operates as a major barrier to discrimination claims based on a pattern of individual decisions - such as racial profiling claims-because a statistical correlation is not sufficient to prove

224. See Farley v. Engelken, 740 P.2d 1058, 1063 (Kan. 1987) (stating that section 1 "affords separate, adequate, and greater rights than the federal Constitution"). The Kansas Supreme Court in Hodes \& Nauser relied on this language. See Hodes \& Nauser MDs, P.A. v. Schmidt, 440 P.3d 461, 470 (Kan. 2019).

225. In some cases, the United States Supreme Court has applied what appears to be a more rigorous form of rational basis review, commonly referred to as "rational basis with bite," to classifications that are not suspect, but are nonetheless motivated by political animus. See, e.g., United States v. Windsor, 570 U.S. 744, 770 (2013) (applying rational basis test to invalidate the federal Defense of Marriage Act's provision excluding valid same-sex marriages from scope of federal statutes finding "improper animus or purpose"); Romer, 517 U.S. at 634-36 (applying rational basis test to invalidate state constitutional amendment precluding laws to protect against discrimination based on sexual orientation); City of Cleburne, 473 U.S. at 445-51 (applying rational basis test to invalidate denial of zoning variance to group home for adults with developmental disabilities); U.S. Dep't of Agric. v. Moreno, 413 U.S. 528, 538 (1973) (applying rational basis test to invalidate federal statute prohibiting award of food stamps to households with multiple unrelated adults). The Kansas courts might apply this sort of rational basis with bite more broadly.

226. See City of Cleburne, 473 U.S. at $442-47$ (declining to recognize mental disability as a suspect classification); Mass. Bd. of Ret. v. Murgia, 427 U.S. 307, 312-15 (1976) (declining to recognize age as a suspect classification); San Antonio Indep. Sch. Dist. v. Rodriguez, 411 U.S. 1, 2730 (1973) (declining to recognize wealth as a suspect classification); see also Windsor, 570 U.S. at 770-75 (applying rational basis with bite without explicitly addressing whether sexual orientation is a suspect classification); Romer, 517 U.S. at 635-37 (1996) (applying rational basis test to invalidate state constitutional amendment precluding laws to protect against discrimination based on sexual orientation).

227. For example, the United States Supreme Court has applied what some regard as a less rigorous form of strict scrutiny to uphold affirmative action programs in higher education. See, e.g., Fisher v. Univ. of Tex., 136 S. Ct. 2198, 2214-16 (2016) (upholding consideration of race as a factor as narrowly tailored to meet the compelling interest in having a diverse student body); Grutter v. Bollinger, 539 U.S. 306, 343-45 (2003) (same). The Kansas Supreme Court might rule that diversity in higher education is not a compelling governmental interest for purposes of section 1 of the Kansas Bill of Rights.

228. Pers. Adm'r v. Feeney, 442 U.S. 256, 281 (1979) (denying the claimant's undue burden claim for lack of "purpose to discriminate on the basis of sex"); Washington v. Davis, 426 U.S. 229, 239 (1976) (requiring a showing of "unequal application of the law to such an extent as to show intentional discrimination"). 
intentional discrimination in any particular case. ${ }^{229}$ Hodes \& Nauser might support an argument in favor of a lower bar for such claims.

In State v. Brooks ${ }^{230}$ and State v. Reed, ${ }^{231}$ for example, the Kansas Appellate Defenders Office argued for greater protections against a prosecutor's discriminatory exercise of peremptory challenges to exclude jurors. ${ }^{232}$ In Batson v. Kentucky, ${ }^{233}$ the United States Supreme Court crafted a three-part framework for proving discriminatory intent in the exercise of the peremptory challenge:

First, a defendant must make a prima facie showing that a peremptory challenge has been exercised on the basis of race. Second, if that showing has been made, the prosecution must offer a race-neutral basis for striking the juror in question. Third, in light of the parties' submissions, the trial court must determine whether the defendant has shown purposeful discrimination. ${ }^{234}$

Although this test was meant to facilitate proof of discriminatory intent, in practice courts accept virtually any race neutral justifications offered by prosecutors, and the test is very easy for prosecutors to satisfy. ${ }^{235}$ The argument in Brooks and Reed for a more protective version of Batson is just the tip of the iceberg of potential equal protection arguments under section 1 .

b. The Death Penalty

Hodes \& Nauser's conclusion that section 1 provides protections that are independent of - and greater than - those provided by the United States Constitution would also arguably apply to the right to life, which is expressly referenced in section 1 as an inalienable natural right. ${ }^{236}$ While

229. See McCleskey v. Kemp, 481 U.S. 279, 314-20 (1987) (declining to find discriminatory intent in the application of the death penalty notwithstanding statistical analysis demonstrating racial correlations).

230. No. 19-120538-A (Kan. Ct. App. filed Jan. 7, 2019).

231. No. 19-120613-A (Kan. Ct. App. filed Jan. 22, 2019).

232. Brief of Appellant at 26, State v. Brooks, No. 19-120538-A (Kan. Ct. App. filed Aug. 13, 2019) ("Under Hodes, section 1 provides more extensive refuge from racial discrimination than the Fourteenth Amendment."); Brief of Appellant at 25, State v. Reed, No. 19-120613-A (Kan. Ct. App. filed Sept. 6, 2019) (same).

233. 476 U.S. 79 (1986).

234. Miller-El v. Cockrell, 537 U.S. 322, 328 (2003) (internal citations omitted) (citing Batson, 476 U.S. at 96-98).

235. See, e.g., Jeffrey Bellin \& Junichi P. Semitsu, Widening Batson's Net to Ensnare More Than the Unapologetically Bigoted or Painfully Unimaginative Attorney, 96 CORNELL L. REV. 1075, 1075 (2011) (concluding, based on a statistical analysis of cases, that Batson is ineffective because it "is easily avoided through the articulation of a purportedly race-neutral explanation for juror strikes").

236. KAN. CONST. Bill of Rights $\S 1$. 
the right to life might be asserted as the foundation for a variety of constitutional claims, ${ }^{237}$ its most direct application would be as a basis for challenging the death penalty in Kansas. ${ }^{238}$ Indeed, Hodes \& Nauser has figured prominently in a series of death penalty cases currently pending before the Kansas Supreme Court: State v. Carr ${ }^{239}$ State v. Cross, ${ }^{240}$ and State v. Flack. ${ }^{241}$ To provide context for discussing this argument, I will begin with some background on the death penalty under federal and state law.

In general terms, although the death penalty is not invalid under the United States Constitution, its application must meet the requirements of due process and cannot violate the Eighth Amendment's prohibition against cruel and unusual punishments. As a result, "a state capital sentencing system must: (1) rationally narrow the class of death-eligible defendants; and (2) permit a jury to render a reasoned, individualized sentencing determination based on a death-eligible defendant's record, personal characteristics, and the circumstances of his crime." 242 The first requirement, which reflects the Eighth Amendment's prohibition on cruel and unusual punishment, limits the death penalty to crimes that are sufficiently heinous to justify its imposition ${ }^{243}$ and prevents its application

237. It might, for example, be asserted as the foundation for a constitutional right of self-defense, on the theory that the right to life implies a corresponding right to protect it. Cf. supra notes 211-13 and accompanying text (discussing claims that the right of self-defense is an inalienable natural right). The right to life might also imply a right to die, in the same way that the right to speak includes the right not to speak or the right to vote includes the right not to vote. Cf. supra notes 202-06 and accompanying text (discussing possibility that the right to die might be a component of the right to make decisions about one's physical health).

238. The Kansas Bill of Rights also contains a prohibition against "cruel or unusual punishment," which might be read as providing independent and greater protections against the imposition of the death penalty than the Eighth Amendment to the United States Constitution, but the focus in recent cases has been on section 1. KAN. CONST. Bill of Rights $\S 9$. See also infra Section III.C (discussing implications of Hodes \& Nauser for other provisions of the Kansas Bill of Rights).

239. See Fifth Supplemental Brief of Appellant, State v. Carr, No. 03-090198-S (Kan. filed Aug. 16, 2019), 2019 WL 3943081; Fifth Supplemental Brief of Appellant, State v. Carr, No. 03-90044-S (Kan. filed Aug. 16, 2019), 2019 WL 3943080. This is really two separate cases involving the infamous Carr brothers, Reginald and Jonathan, who were convicted of a famous and brutal crime spree known as the "Wichita Massacre." See State v. Carr, 331 P.3d 544 (Kan. 2014) (per curiam) (affirming convictions but setting aside death penalty), rev'd, $136 \mathrm{~S}$. Ct. 633 (2016) (concluding that Kansas Supreme Court had improperly set aside the death penalty). The crime has its own Wikipedia page. See Wichita Massacre, WIKIPEDIA, https://en.wikipedia.org/wiki/Wichita_Massacre [https:// perma.cc/A5RV-NLHF] (last visited Mar. 30, 2020).

240. See Supplemental Brief of Appellant, State v. Cross, No. 15-114919-S (Kan. Aug. 16, 2019), 2019 WL 3943082.

241. See Supplemental Brief of Appellant, State v. Flack, No. 16-115964-S (Kan. Aug. 16, 2019), 2019 WL 3943083.

242. Kansas v. Marsh, 548 U.S. 163, 173-74 (2006).

243. See, e.g., Kennedy v. Louisiana, 554 U.S. 407 (2008) (holding that it violated the Eight Amendment to impose the death penalty for the rape of a child that neither was intended to nor did result in her death). 
to individuals who lack the requisite culpability. ${ }^{244}$ The second requirement, which reflects due process considerations, necessitates a sentencing phase in which the jury hears a broad range of aggravating and mitigating factors in a way that is individualized, but also guards against the arbitrary imposition of the death penalty. ${ }^{245}$

To this point, the Kansas Supreme Court has relied on federal doctrine when considering the validity of death penalty statutes. In State v. Kleypas ${ }^{246}$ for example, the court applied federal doctrine to uphold the Kansas death penalty statute, although it also concluded that the state could not provide for the imposition of the death penalty when the aggravating and mitigating factors were evenly balanced. ${ }^{247}$ The Kansas Supreme Court later relied on the Kleypas limitation to set aside the death penalty in State v. Marsh, ${ }^{248}$ but the United States Supreme Court reversed, concluding that Kleypas and Marsh had misread the Court's death penalty precedents. $^{249}$

More recently, in Kansas v. Carr ${ }^{250}$ the United States Supreme Court again reversed Kansas Supreme Court decisions that applied federal doctrine to set aside the death penalty. In State v. Gleason ${ }^{251}$ and State v. Carr ${ }^{252}$ the Kansas Supreme Court set aside the imposition of the death penalty in particular cases because the trial court failed to instruct jurors that a defendant need only prove by a preponderance of the evidence that the mitigating factors outweighed the aggravating factors. The United States Supreme Court, which consolidated these decisions for review, rejected this conclusion. ${ }^{253}$ The United States Supreme Court also rejected

244. See, e.g., Roper v. Simmons, 543 U.S. 551 (2005) (holding that imposition of the death penalty on juveniles is unconstitutional because of their diminished culpability); Atkins v. Virginia, 536 U.S. 304 (2002) (holding that imposition of death penalty on defendants with significant developmental disabilities is unconstitutional).

245. See, e.g., Kansas v. Carr, 136 S. Ct. 633 (2016) (rejecting the Kansas Supreme Court's conclusion that conduct of sentencing phase was constitutionally flawed); Kansas v. Marsh, 548 U.S. 163 (2006) (rejecting the Kansas Supreme Court's conclusion that the state could not shift the burden of proving mitigating factors on the defendant once aggravating factors had been proved).

246. 40 P.3d 139 (Kan. 2001) (per curiam).

247. Id. at 223-34.

248. 102 P.3d 445, 458 (Kan. 2004), rev'd, 548 U.S. 163 (2006) (also abrogating Kleypas in part).

249. Marsh, 548 U.S. at 181.

250. Carr, 136 S. Ct. at 643-46 (reversing both Gleason and Carr on the issue of instructions and Carr on the issue of severing the sentencing hearings).

251. 329 P.3d 1102, 1147 (Kan. 2014) (per curiam) (“[C]apital juries in Kansas must be informed that mitigating circumstances need not be proven beyond a reasonable doubt.").

252. 331 P.3d 544, 707 (Kan. 2014) (per curiam) (concluding that trial court erred "in failing to instruct the jury that the existence of mitigating factors need not be proved beyond a reasonable doubt"). The Kansas Supreme Court also concluded in Carr that the trial court erred "in refusing to sever the penalty phase of the defendants' trial." Id. at 706-07.

253. Carr, $136 \mathrm{~S}$. Ct. at $642-44$. 
the Kansas Supreme Court's ruling in Carr that the trial court had improperly refused to sever the sentencing phase of the codefendants' trial. ${ }^{254}$

The Kansas Supreme Court's recent history thus suggests that it might be receptive to arguments for more extensive constitutional protections against the death penalty under state, as opposed to federal, law. In particular, the Kansas Supreme Court might conclude that even if federal doctrine permits the state to require a defendant to prove that the mitigating factors outweigh the aggravating factors, section 1 of the Kansas Bill of Rights does not. On the other hand, the Kansas Supreme Court affirmed the imposition of the death penalty after remand in Gleason, ${ }^{255}$ which suggests a willingness to adhere to federal doctrine even when it was less protective than the Kansas Supreme Court had thought. Nonetheless, Gleason was decided before Hodes \& Nauser, which arguably signals a greater willingness to decide individual rights questions on the basis of state, rather than federal, law.

The defendants' briefs in Carr, Cross, and Flack, however, rely on Hodes \& Nauser to advance a broader challenge to the state's death penalty statute. ${ }^{256}$ These briefs argue that strict scrutiny should apply to the death penalty statute because the right to life is expressly protected as fundamental under section 1 of the Kansas Bill of Rights, and that the current statute fails strict scrutiny because it is not narrowly tailored to further a compelling governmental interest. ${ }^{257}$ The state, in its response, argues that Hodes \& Nauser is not relevant to the death penalty because courts do not apply fundamental rights analysis to criminal processes and lawfully imposed sentences do not violate fundamental rights. ${ }^{258}$

254. Id. at $644-46$.

255. State v. Gleason, 388 P.3d 101, 116 (Kan. 2017).

256. See Appellant's Reply Brief to Fifth Supplemental Brief of Appellee, State v. Carr, No. 0390044-S (Kan. filed Nov. 8, 2019), 2019 WL 6027161; Appellant's Reply Brief to Supplemental Brief of Appellee, State v. Carr, No. 03-90198-S (Kan. filed Nov. 7, 2019), 2019 WL 6027162; Fifth Supplemental Brief of Appellant, State v. Carr, No. 2003-090044-S (Kan. filed Aug. 16, 2019), 2019 WL 3943080; Supplemental Brief of Appellant, State v. Carr, No. 2003-090198-S (Kan. filed Aug. 16, 2019), 2019 WL 3943081; Appellant's Reply Brief to Supplemental Brief of Appellee, State v. Cross, No. 15-114919-S (Kan. filed Nov. 8, 2019), 2019 WL 6027163; Supplemental Brief of Appellant, State v. Cross, No. 15-114919-S (Kan. filed Aug. 16, 2019), 2019 WL 3943082; Appellant's Reply Brief to Supplemental Brief of Appellee, State v. Flack, No. 16-115964-S (Kan. filed Nov. 7, 2019), 2019 WL 6027164; Supplemental Brief of Appellant, State v. Flack, No. 16115964-S (Kan. filed Aug. 16, 2019), 2019 WL 3943083.

257. In particular, according to the defendants' argument, the state's interest in retribution is not compelling and the current death penalty is not narrowly tailored to meet the state's compelling interest in deterrence.

258. See Appellee's Supplemental Brief in Response to Appellant's Fifth Supplemental Brief at 4-17, State v. Carr, No. 03-90044-S (Kan. filed Oct. 15, 2019); Appellee's Supplemental Brief in 
Applying strict scrutiny to invalidate the death penalty would require the Kansas Supreme Court to overrule Kleypas, which it reaffirmed only two years ago in State v. Kahler. ${ }^{259}$ The court also seemed reluctant to address broad challenges to the death penalty in Carr and Gleason. ${ }^{260}$ Nonetheless, similar considerations did not sway the court in Hilburn $v$. Enerpipe Ltd. ${ }^{261}$ discussed below, which relied on Hodes \& Nauser to overrule recent decisions and recognize a constitutional claim with potentially sweeping implications. ${ }^{262}$ Accordingly, the court's decisions in Carr, Cross, and Flack bear watching.

\section{Implications for Other Kansas Bill of Rights Provisions}

The Kansas Constitution's Bill of Rights contains a number of other provisions protecting a variety of other rights, ${ }^{263}$ including some with federal counterparts ${ }^{264}$ and some for which there is no corresponding federal constitutional provision. ${ }^{265}$ Although Hodes \& Nauser focused on interpreting and applying section 1, its analysis may have significance for the interpretation and application of these other Kansas Bill of Rights provisions. First, Hodes \& Nauser may support interpreting these other provisions to afford independent protections that exceed those given by the United States Constitution, even when the Kansas provisions are similar to federal provisions. Second, Hodes \& Nauser indicated that the usual presumption of constitutionality, as reflected in the deferential

Response to Appellant's Supplemental Brief, State v. Carr, No. 03-90198-S (Kan. filed Oct. 15, 2019); see also Brief of Appellee at 93, State v. Flack, No. 2016-115964-S (Kan. filed Oct. 1, 2019), 2019 WL 4925015 (ignoring Hodes \& Nauser and arguing simply that the state should adhere to its precedents upholding the death penalty).

259. 410 P.3d 105 (Kan. 2018), cert. granted, 139 S. Ct. 1318 (U.S. Mar. 18, 2019) (No. 18-6135) (granting certiorari on the issue of whether the Eighth and Fourteenth Amendments permit states to abolish the insanity defense).

260. See State v. Carr, 331 P.3d 554, 708 (Kan. 2014) (per curiam) (declining to reach issues of whether "the death penalty [is] an unconstitutionally disproportionate punishment as applied to aiders and abettors of capital murder" and whether "Kansas' execution protocol protect[s] against unnecessary pain"); State v. Gleason, 329 P.3d 1102, 1148 (Kan. 2014) (per curiam) ("Because we are vacating Gleason's death sentence, we decline to consider his constitutional and statutory challenges to the death penalty.").

261. 442 P.3d 509 (Kan. 2019)

262. Id. (overruling Miller v. Johnson, 289 P.3d 1098 (Kan. 2012), Samsel v. Wheeler Transp. Servs., Inc., 789 P.2d 541 (Kan. 1990), and Kan. Malpractice Victims Coal. v. Bell, 757 P.2d 251 (Kan. 1988)). For further discussion of Hilburn, see infra notes 266-81 and accompanying text.

263. See generally KAN. CONST. Bill of Rights $\S \S 1-21$ (enumerating various rights).

264. See, e.g., id. § 3 (right of peaceable assembly); id. § 4 (right to bear arms); id. § 11 (freedom of speech and press); id. $\S 15$ (prohibiting unreasonable searches and seizures).

265. See, e.g., id. $\S 2$ (declaring political power to rest in the people and prohibiting grant of special privileges and immunities); id. § 12 (prohibiting forfeiture of estates for crimes); id. § 16 (prohibiting imprisonment for debt); id. $\S 21$ (right to hunt, fish, and trap wildlife). 
rational basis test, does not apply when a state law burdens rights protected in the Kansas Bill of Rights.

The Kansas Supreme Court has already used this sort of analysis in Hilburn v. Enerpipe Ltd., ${ }^{266}$ which invalidated K.S.A. $\S 60-19 a 02$, a statutory cap on noneconomic damages. The court had previously upheld the statute in Miller $v$. Johnson, ${ }^{267}$ which rejected challenges based on section 5 and section 18 of the Kansas Bill of Rights. Section 5 declares that "[t]he right of trial by jury shall be inviolate" 268 and section 18 specifies that "[a]ll persons, for injuries suffered in person, reputation or property, shall have remedy by due course of law, and justice administered without delay." 269

Miller merged the analysis under these two provisions, ruling that the legislature must provide an "adequate and viable substitute when modifying a common-law jury trial right under Section 5 or right to remedy under Section 18." ${ }^{270}$ In other words, the legislature may limit traditional judicial remedies subject to trial by jury if it provides a "quid pro quo" that offsets the diminishment of a parties' common law claim. The court in Miller concluded that the legislature had provided such a quid pro quo because K.S.A. $\S 60-19 \mathrm{a} 02$ was part of a broader system designed to ensure that the availability of funds to pay damages. Thus, the court reasoned, "having an available source of recovery of the statutorily mandated minimums provides [a plaintiff] with a significant, individualized substitute remedy." ${ }^{27}$

Hilburn, however, concluded that this quid pro quo analysis is inappropriate for section 5 challenges, overruling Miller and invalidating K.S.A. $\S 60-19 \mathrm{a} 02$ as a denial of the right to a jury trial. ${ }^{272}$ In so doing, the court began by relying on Hodes \& Nauser to conclude that no presumption of constitutionality should apply because "the right protected by section 5 is a 'fundamental interest' expressly protected by the Kansas Constitution Bill of Rights." 273 The court then engaged in an extensive

266. 442 P.3d 509, 524 (Kan. 2019) (invalidating statutory noneconomic damages cap)

267. 289 P.3d 1098, 1109-25 (Kan. 2012).

268. KAN. CONST. Bill of Rights $\S 5$.

269. Id. § 18 .

270. 289 P.3d at 1113 . To satisfy the quid pro quo analysis, the court applies a two-step analysis: "For step one, we determine whether the modification to the common-law remedy or the right to jury trial is reasonably necessary in the public interest to promote the public welfare." Id. at 1114 . The first step is, in essence, the rational basis test. $I d$.

271. Id. at 1117 .

272. The court therefore found it unnecessary to consider the section 18 challenge. See Hilburn v. Enerpipe Ltd., 442 P.3d 509, 511 (Kan. 2019) ("This decision eliminates any necessity of addressing Hilburn's section 18 claim.").

273. Id. at 513 . 
discussion of the quid pro quo test, concluding that it was inconsistent with the text of section 5 and that the precedents relied on in Miller did not support the application of the test in section 5 (as opposed to section 18) cases. $^{274}$ The court then applied an apparently per se rule that prevents the legislature from displacing the jury's finding of fact, including its findings regarding the amount of damages. ${ }^{275}$

Hilburn has potentially important implications for other cases involving section $5,{ }^{276}$ as well as for the application of section 18 . Consider, for example, the Kansas Workers Compensation scheme, which replaces traditional common law tort remedies with an administrative system in which compensation is paid according to legislatively determined schedules. ${ }^{277}$ The Kansas courts have upheld the system, concluding that it was rationally related to a legitimate state interest and provided an adequate quid pro quo. ${ }^{278}$ Hilburn suggests that the workers compensation law, at least in its current form, might be vulnerable to a challenge under section 5 and section 18 .

To the extent that the workers compensation system replaces tort actions subject to trial by jury with an administrative remedy determined without a jury, it may implicate section 5 of the Kansas Bill of Rights. Indeed, both Miller and Hilburn referenced concerns that refusal to apply a quid pro quo analysis under section 5 might mean that the workers compensation system was unconstitutional. The court in Miller relied on this concern to support the application of quid pro quo analysis under section 5. ${ }^{279}$ The court in Hilburn, however, suggested that these concerns were misplaced because "[t]he new administrative system of no-fault

274. See id. at $514-21$.

275. Id. at 524 ("Regardless of whether an existing damages cap is technically or theoretically applied as a matter of law, the cap's effect is to disturb the jury's finding of fact on the amount of the award. Allowing this substitutes the Legislature's nonspecific judgment for the jury's specific judgment. The people deprived the Legislature of that power when they made the right to trial by jury inviolate.").

276. See Brief of Appellant at 31-34, State v. Owens, No. 19-120753-S (Kan. filed Oct. 10, 2019), 2019 WL 5268837 (relying on Hodes \& Nauser to argue that judicial restitution order in criminal sentencing violated section 5).

277. KAN. STAT. ANN. $\S \S 44-501$ to -5127 (West 2018).

278. See, e.g., Injured Workers of Kan. v. Franklin, 942 P.2d 591 (Kan. 1997). The Kansas Court of Appeals, however, invalidated the most recent amendments to the schedule of compensation on the ground that they went too far in reducing the level of compensation so that there was no longer an adequate quid pro quo. See Johnson v. U.S. Food Serv., 427 P.3d 996 (Kan. Ct. App. 2018) (invalidating KAN. STAT. ANN. $\S \S 44-510 \mathrm{~d}(\mathrm{~b})(23)-(24),-510 \mathrm{e}(\mathrm{a})(2)(\mathrm{B}))$; see also Pardo v. United Parcel Serv., 422 P.3d 1185 (Kan. Ct. App. 2018) (invalidating KAN. STAT. ANN. § 44-510d(b)(23) as applied on the facts).

279. See Miller v. Johnson, 289 P.3d 1098, 1112 (Kan. 2012) (reasoning that retreating from the quid pro quo analysis "would collaterally create uncertainty about the constitutionality of the Workers Compensation Act"). 
compensation for injured workers left no common-law cause of action upon which Section 5's jury trial right could act." ${ }^{280}$ Under this analysis, the right to a jury only attaches if there is a common law cause of action tried in a court of law, and section 5 would not constrain the legislature's authority to replace common law rights with administrative remedies. ${ }^{281}$

In other words, the legislature's authority to replace common law causes of action with administrative remedies would be constrained only by section 18 , which under current doctrine allows such measures if there is a rational basis for replacing the common law remedy with an administrative compensation system and the administrative compensation system is an adequate quid pro quo. ${ }^{282}$ Insofar as a remedy by due course of law is explicitly protected under section 18, the rational basis test arguably should no longer apply to laws that eliminate common law remedies. ${ }^{283}$ In addition, courts should arguably be less deferential when assessing the adequacy of the statutory quid pro quo. ${ }^{284}$ This result would

280. Hilburn, 442 P.3d at 520 (quoting Miller, 289 P.3d at 1145 (Beier, J., concurring in part and dissenting in part)).

281. Under federal law, by way of contrast, the Seventh Amendment right to a jury trial applies to administrative adjudications, which may be invalid if they deny the right to trial by jury. See Atlas Roofing Co., Inc. v. Occupational Safety \& Health Review Comm'n, 430 U.S. 442 (1977). In most cases, however, administrative adjudication of "public rights" is constitutionally permissible because such rights were traditionally adjudicated by courts of equity without a jury. Id. at 450 . In any event, however, the Seventh Amendment, does not apply to the states, so this analysis would not be controlling. See McDonald v. City of Chicago, 561 U.S. 742, 765, n.13 (2010) (listing the Seventh Amendment as among the "handful of the Bill of Rights protections" that have not been incorporated by the Due Process Clause of the Fourteenth Amendment so as to be applicable to the states).

282. See, e.g., Franklin, 942 P.2d at 603 ("If a remedy protected by due process is abrogated or restricted by the legislature, such change is constitutional if [1] the change is reasonably necessary in the public interest to promote the general welfare of the people of the state, and [2] the legislature provides an adequate substitute remedy to replace the remedy which has been restricted." (internal quotation marks and citations omitted) (quoting Lemuz v. Fieser, 933 P.2d 134, 144 (Kan. 1997))).

283. For example, in Tillman v. Goodpasture, the Kansas Court of Appeals relied on the presumption of constitutionality to hold that a Kansas statute prohibiting medical malpractice claims based on "wrongful life or wrongful birth" did not implicate section 5 or section 18 because those provisions only protect causes of action that existed at common law when the Kansas Bill of Rights was adopted. 424 P.3d 540, 543 (Kan. Ct. App. 2018) (quoting KAN. STAT. ANN. § 60-1906(a)). If the Kansas Supreme Court were to treat the cause of action in question as a species of medical malpractice action, a type of action that did exist when the Bill of Rights was adopted, then the statute might implicate section 18. If so, then strict scrutiny, rather than the rational basis test, arguably should apply.

284. An injured worker made this argument in the pending appeal to the Kansas Supreme Court in Johnson v. U.S. Food Service, which invalidated K.S.A. § 44-510d(b)(23)-(24) and K.S.A. § 44$510 \mathrm{e}(\mathrm{a})(2)(\mathrm{B})$ because they reduced compensation to the point that the workers compensation law no longer provided an adequate pro quo. 427 P.3d 996 (Kan. Ct. App. 2018). See also Supplemental Brief of Appellant at 4-5, Johnson v. U.S. Food Serv., No. 17-117725-S (Kan. filed June 21, 2019), 2019 WL 3081266 (relying on Hodes \& Nauser to argue that "there is no presumption of constitutionality in cases dealing with 'fundamental interests' protected by the Kansas Constitution" and that $\S 18$, like $\S 5$, is a fundamental right so that in such cases "there is no presumption of constitutional validity"). 
present a serious problem for the current workers compensation system, insofar as substantive rules protecting workers and levels of compensation have eroded to the point that there is arguably no longer an adequate quid pro quo for the elimination of common law tort actions. ${ }^{285}$

More broadly, Hilburn raises the question what other rights under the Kansas Bill of Rights might be considered to be fundamental so as to preclude the presumption of constitutionality and justify heightened protection under strict scrutiny, per se rules, or other more rigorous forms of judicial review. Thus, for example, in a series of cases the Kansas Appellate Defenders Office has relied on Hodes \& Nauser to argue for strict scrutiny of laws implicating the right to keep and bear arms under section $4 .{ }^{286}$ Similarly, in State v. Beasely, ${ }^{287}$ a defendant argued that the trial court violated section 16 of the Kansas Bill of Rights, which prohibits imprisonment for debt, by extending his probation solely on the basis of an outstanding debt. ${ }^{288}$ As this Article was in process, moreover, the Kansas Attorney General cited Hodes \& Nauser as additional authority to support his conclusion that the "religious freedom protections in the Kansas Constitution's Bill of Rights ... exceed the religious freedom protections in the federal Constitution." 289

285. See Franklin, 942 P.2d at 620 (reviewing 1993 amendments to the workers compensation act that made "the quid pro quo for the abrogation of the employees' common-law right to sue an employer for negligence . . . less than what it was prior to 1993" but nonetheless upholding the law); id. at 62324 (Allegrucci, J., dissenting) (observing that "when the legislature provides a substitute remedy," it "cannot alter the remedy to the point "it is no longer a viable and sufficient substitute remedy," and concluding that "the Workers Compensation Act, as amended, no longer provides an adequate quid pro quo" (quoting Bair v. Peck, 811 P.2d 1176, 1191 (Kan. 1991))); see also Blake Saffels, "Death by a Thousand Paper Cuts"-How the Kansas Supreme Court Should Stop the State Legislature's Systematic Decimation of Workers Compensation Benefits, 69 U. KAN. L. REV. (forthcoming 2020) (discussing legislative actions undermining the Kansas workers compensation system's quid pro quo in light of Hodes \& Nauser).

286. See Brief of Appellant at 22-27, State v. Valdez, No. 19-121053-A (Kan. Ct. App. filed Dec. 31, 2019), 2019 WL 7505167 (relying on Hodes \& Nauser to challenge statutory provision prohibiting possession of firearms by certain convicted felons); Brief of Appellant at 30-34, State v. Smith, No. 2019-121332-A (Kan. Ct. App. filed Dec. 23, 2019), 2019 WL 7347473 (same); Brief of Appellant at 37-40, State v. Guebara, No. 18-120994-A (Kan. Ct. App. filed Dec. 5, 2019), 2019 WL 6709204 (same); Brief of Appellant at 19-24, State v. Baumgarner, No. 19-121092-A (Kan. Ct. App. filed Nov. 19, 2019), 2019 WL 6340190 (relying on Hodes \& Nauser to argue that statutory ban on possession of firearm by mentally ill persons subject to involuntary civil commitment violated section 4); Brief of Appellant at 29-34, State v. Celestine, No. 19-121091-A (Kan. Ct. App. filed Nov. 18, 2019), 2019 WL 6340189 (relying on Hodes \& Nauser to challenge statutory provision prohibiting possession of firearms by certain convicted felons); Brief of Appellant at 6-21, State v. Johnson, No. 19-121187-A (Kan. Ct. App. filed Oct. 25, 2019), 2019 WL 5640039 (same).

287. No. 19-120,477-A (Kan. Ct. App. filed Dec. 21, 2018).

288. Brief of Appellant at 5-12, State v. Beasley, No. 19-120,477-A (Kan. Ct. App. filed Dec. 5, 2019), 2019 WL 6709205.

289. Memorandum from Derek Schmidt, Kan. Att'y Gen., to Kan. Prosecutors \& Law Enf't 5 (Apr. 8, 2020), https://ag.ks.gov/docs/default-source/documents/addendum-1-to-law-enforcement 
It remains to be seen whether the Kansas Supreme Court will recognize other Bill of Rights protections as fundamental so as to preclude a presumption of constitutionality and justify the application of higher standards of review. Arguably, any right expressly included in the Kansas Bill of Rights should be considered fundamental. Indeed, Justice Stegall, who concurred in Hilburn, objected to the recognition of some rights, but not others, as fundamental, suggesting that "[p]erhaps courts should exercise de novo review over Kansas statutes when any portion of our Constitution is implicated, not only when judicially favored rights are involved. ${ }^{290}$

\section{CONCLUSION}

The Kansas Supreme Court decision in Hodes \& Nauser has profound implications for constitutional rights in Kansas. The decision is a declaration of independence from the United States Supreme Court's current constitutional rights jurisprudence, not only with respect to abortion rights, but also with respect to a potentially broad array of other rights.

The full import of the decision remains to be seen, but in Hilburn the Kansas Supreme Court already relied on Hodes \& Nauser to provide expanded protection for the right to a jury trial, overruling recent precedent to the contrary. Litigants have begun to rely on Hodes \& Nauser in support of a variety of other constitutional claims. Some of these claims, like other challenges to anti-abortion laws, the asserted right of self-defense, enhanced equal protection safeguards, and challenges to the death penalty, arise under section 1. Others assert enhanced protections under additional provisions of the Kansas Bill of Rights, including sections 4, 5, 16, and 18. Still other rights claims may be forthcoming.

Some final observations about the decision are also in order. First, even if right to life advocates succeed in overruling the holding of Hodes $\&$ Nauser by a constitutional amendment eliminating the right to abortion, such a result would not affect the court's underlying analysis. Thus, Hodes $\&$ Nauser, bolstered by Hilburn, would continue to support the principle that the Kansas Constitution provides independent and greater protection

\footnotetext{
-duties-and-authorities-memo.pdf?sfvrsn=7a60ac1a_2 [https://perma.cc/M6E2-FUFQ] (advising law enforcement personnel not to enforce Kansas Governor's emergency order extending prohibition on mass gatherings to religious gatherings so as to prevent spread of COVID-19). The Kansas Attorney General first cited State v. Smith, 127 P.2d 518 (Kan. 1942), as direct authority for the proposition in text, and added the reference to Hodes \& Nauser as a "see also generally" reference, with the explanatory parenthetical: "(recognizing that the Kansas Constitution's limits on government action may exceed federal limits)." Id.

290. Hilburn v. Enerpipe, Ltd., 442 P.3d 509, 527 (Kan. 2019) (Stegall, J., concurring in part).
} 
for rights than the United States Constitution. Those decisions would also continue to support the rejection of any presumption of constitutionality and the application of strict scrutiny or other heightened forms of judicial review when laws implicate provisions of the Kansas Bill of Rights.

Second, Hodes \& Nauser represents a significant assertion of judicial authority to limit legislative and executive actions. This assertion of judicial power is neither inherently liberal nor inherently conservative, even if the specific results in Hodes \& Nauser and Hilburn may seem to reflect a "liberal" ideology. Enhanced protections for the right to keep and bear arms, for example, is hardly a "liberal" position as that term is currently understood. Likewise, the logic of Hodes \& Nauser would arguably support greater protections for traditionally conservative rights like freedom of contract, property rights, or the pursuit of a calling, which currently receive little or no protection under federal doctrine.

We cannot be sure exactly what Hodes \& Nauser will mean for constitutional doctrine in Kansas, but we can be sure that the landscape of constitutional rights in the state is in the midst of profound change. 